\title{
GROUP AFFILIATION AND THE PERFORMANCE OF INITIAL PUBLIC OFFERINGS IN THE INDIAN STOCK MARKET ${ }^{1}$
}

\author{
Vijaya B Marisetty ${ }^{2}$ \\ and \\ Marti G Subrahmanyam ${ }^{3}$
}

\footnotetext{
${ }^{1}$ We thank Heitor Almeida, Bhagwan Chowdhary, Alexander Ljungqvist and Jay Ritter for their comments on previous drafts of this paper. We also acknowledge helpful comments from the discussant, Reena Aggarwal, and other participants at the 2006 WFA meetings, Keystone, Colorado, USA. We thank Subrata Mukherjee and J. Niranjan of ICICI Securities and Finance Co. Ltd. for providing us with data on the league tables of Indian investment banks and for helpful discussions on the allotment process for IPOs in India. We are grateful to an anonymous referee for detailed comments on a previous draft of the paper, which lead to additional tests and an improvement in the exposition. This study was completed when Vijaya Marisetty was a post-doctoral fellow at the Indian School of Business (ISB), Hyderabad, India and a visiting scholar at the Wharton School of Business, University of Pennsylvania. He thanks ISB for generous support to carry out this research.

2 Department of Accounting and Finance. Address: Monash University518, Building N, Caulfield Campus, Monash University, Caulfield, Vic 3145, Australia. Tel: +61 39903 2652. Fax: +61 39903 2422. Email: vijay.marisetty@buseco.monash.edu.au

${ }^{3}$ Corresponding author. Stern School of Business, New York University. Address: Leonard Stern School of Business, Kaufman Management Center, 44 West 4th Street, New York, NY 10012, USA. Tel: +1 212998 0348. Fax: +1 212995 4233. Email: $\underline{\text { msubrahm@stern.nyu.edu }}$
} 


\title{
GROUP AFFILIATION AND THE PERFORMANCE OF INITIAL PUBLIC OFFERINGS IN THE INDIAN STOCK MARKET
}

\begin{abstract}
We document the effects of group affiliation on the initial performance of 2,713 Initial Public Offerings (IPOs) in India under three regulatory regimes during the period 1990-2004. We distinguish between two competing hypotheses regarding group affiliation: the "certification" and the "tunneling" hypotheses. We lend support to the latter by showing that the underpricing of group companies is higher than that of stand-alone companies. We ascribe the higher initial returns of group IPOs to investor overreaction. Ex post, we find that group-affiliated companies have a higher probability of survival over the long term: groups support their affiliates to maintain their reputation.
\end{abstract}

JEL Classification: G14, G32.

Key Words: Initial Public Offering (IPO), Underpricing, Business Groups, Certification, Tunneling. 


\section{Introduction}

The decision to go public through an Initial Public Offering (IPO) is one of the most critical decisions in the life cycle of a firm. Due to its presumed importance, it has become one of the most widely researched topics in the finance literature. One aspect of this literature is the use of some form of certification to reduce the costs associated with an IPO. To alleviate the costs associated with the IPO decision, firms often build their reputation by obtaining different types of quality certifications to signal their true value to the market. Some popular certification strategies include employing a reputable auditor [see Beatty, 1989], associating with a venture capitalist with an established track record [see Barry, Muscarella, Peavy and Vetsuypens (1990)], hiring a well-known underwriter [see Carter, Dark and Singh (1998)], attracting strong institutional affiliation [see Hamao, Packer and Ritter (2000)], and recruiting a good quality management team [see Chemmanur and Paeglis (2005)]. ${ }^{1}$

One form of certification, popular in many countries where family-controlled businesses play a dominant role in the economy, is affiliation to a business group. In this paper, we aim to address three main issues related to business group affiliation and initial firm performance in the Indian context:

1. Does affiliation with a private business group, domestic Indian or foreign, act as a form of certification at the time of the IPO, as reflected in its initial underpricing?

2. Does the long-run survival/success probability of such group-affiliated companies differ from that of stand-alone companies?

3. How do IPOs of firms that are affiliated with business groups, both Indian and foreign, perform in the long run in terms of returns to investors?

These questions arise in the context of the family business structure which dominates a vast proportion of enterprises in India. Ownership and control by families is common for many companies in the emerging market countries in Asia and Latin America, as well as in some industrialized countries in Europe. Hence, group affiliation is an important global issue that has an impact on firms in many parts of the world, and in turn, on their financial markets. A specific

\footnotetext{
${ }^{1}$ There is a vast literature on the role of certification in IPOs. We do not attempt to survey this literature in any detail here, but rather provide a few examples to set our research in context.
} 
instance of this broad picture is in India, where large family-owned business groups control several firms through complex cross-holdings.

On the one hand, group affiliation can be considered to be a positive signal by investors as the company is perceived to be backed by established promoters with a track record of performance. This argument is in line with the certification hypothesis, on the assumption that investors face less uncertainty regarding a firm's value, due to its affiliation with a group, thus leading to less underpricing of the IPO. On the other hand, however, the recent literature on family-owned business groups, particularly in the Asian context, reveals that many of the controlling owners of family-owned business groups may "tunnel" the cash flows from companies in which they have low cash flow rights to companies in which they have high cash flow rights, relative to their control rights [see Faccio, Lang and Young (2001) and Faccio and Lang (2002), for example]. This evidence suggests that group affiliation may act as a negative signal regarding a firm's value. Thus, the complexity associated with cross-holdings between group companies increases outside investors' uncertainty, leading to greater underpricing. Therefore, there are two competing hypotheses regarding the effect of group certification on firms' initial performance: the "certification" hypothesis, which predicts lower underpricing for group-affiliated companies, and the "tunneling" hypothesis, which predicts the opposite.

We aim to bring greater clarity to our understanding of the evolution of pyramidal groups, in which companies are connected by a hierarchical structure of ownership relationships, by studying the effect of group affiliation on firm performance. The existing literature on pyramidal organizations does not attempt to disentangle the web of such organizations. Rather, so far, most of the papers focus on the effect of group affiliation on firm performance (based on accounting and market variables) as measured on an ex post basis. In contrast, we attempt to address part of the pyramidal organizations' evolutionary process, by examining whether the market recognizes group affiliation as a positive or a negative signal, right at the point where public investors are considering acquiring ownership. In this context, we also address the endogeneity problem that is associated with most of the studies related to ownership structure and firm performance [see Demsetz and Lehn (1985)]. The observed relationship of ownership structure to firm value at a given point of time can be the outcome of market forces, which react to the ownership structure. Thus, any significant relationship may be spurious. However, if the relationship is measured at the time of a firm's initial entry into the stock market, the 
endogeneity problem will not affect the causal relationship between ownership structure, as defined by group affiliation, and firm value.

To our knowledge, this is the second paper that addresses the ex-ante effects of group affiliation and the market's perception of firm value. The first was a paper by Dewenter, Novaes and Pettway (2001), which addressed the effects of group affiliation and the initial performance for the IPOs of Japanese firms affiliated with business groups. They conclude that groupaffiliated companies pay higher costs in the form of higher IPO underpricing due to the additional costs incurred by investors to analyze the complexity associated with group-affiliated companies.

Our study differs from that of Dewenter et al. [2001] in at least five respects. First, the institutional features, economic environment and the group structure vary significantly between India and Japan [see Khanna and Palepu (1997) and (2000)]. Second, their sample includes only 159 IPOs that were issued in Japan between 1981 and 1994. Our study uses a more recent time period (1990-2004) and is based on a much larger sample size (2,713 IPOs).

Third, apart from the IPOs of companies affiliated with domestic groups (as in the Dewenter et al., 2001 study), we also study those of companies affiliated with private foreign groups and the government. (This classification is not peculiar to India and is relevant in many other emerging market countries.) Foreign groups are typically large multinational corporations that are thought of as more efficient and transparent in their corporate governance practices. On the other hand, since the company going public is typically a subsidiary of the multinational company, there is an inherent conflict of interest between the parent and these subsidiaries, with regard to various transfer payments for the use of brands, technology and corporate services. Companies controlled by the governments, both state and central, are often regarded as being subject to political and bureaucratic interference, and therefore are not looked upon favorably by investors. On the other hand, these companies are subject to closer public scrutiny through oversight bodies empowered by the state legislatures and the national parliament. The question we wish to examine is whether the market views the IPOs of companies in the three groups somewhat differently. We are also able to investigate the effects of structural changes in the market and in the regulatory framework, since the period of our study spans three different regulatory regimes in India. During this period, the Indian economy emerged from a highly regulated, state-controlled structure to a relatively liberalized, open one. 
Fourth, we examine, on an ex post basis, the performance of companies after the IPO. Our analysis casts some light on the subsequent evaluation of group affiliation well after the IPO, and presents a more complete picture of changing market perceptions over time. Last, but not least, as an alternative explanation to the one proposed by Dewenter et al. [2001], for greater underpricing of group-affiliated firms, we propose and test the over-reaction hypothesis in the context of IPOs. We argue that the opaqueness of the IPO process may not be the explanation for this phenomenon in the Indian context; rather, it is investors' interest in the new issues of groupaffiliated firms that drives higher underpricing of the group affiliated firm IPOs compared to their stand-alone counterparts.

Our overall conclusion, similar to Dewenter et al. [2001], is that group-affiliated companies experienced greater underpricing than their stand-alone counterparts in their IPOs. However, we cannot concur with the conclusion of Dewenter et al. [2001] that underpricing occurs to offset the cost of the complexity associated with group companies. This is because we find IPOs of foreign group-affiliated companies also exhibit higher underpricing than domestic group-affiliated companies. If we used the argument of Dewenter et al. [2001], we would expect that private foreign groups should be more complex, with numerous chains of cross holdings. However, most of the (parent) private foreign groups in our sample are large multinational companies based in the United States and the United Kingdom. These groups do not generally have complex cross holdings and are presumed to abide by more stringent disclosure norms. ${ }^{2}$ Thus, we can attribute the higher underpricing of the IPOs of companies affiliated with groups to the "tunneling" activities of the controlling groups, perhaps accentuated by investor overreaction at the time of the IPO.

Using data on investor over-subscription, a proxy for investor overconfidence, we also provide evidence that behavioral models may explain the higher underpricing of group firm IPOs better than traditional information asymmetry arguments used by Dewenter et.al. [2001]. ${ }^{3}$ We

\footnotetext{
${ }^{2}$ However, as pointed out earlier, private foreign groups may have a conflict of interest between the Indian affiliate and the overseas parent, due to royalties and other transfer payments paid to the parent, which may partly explain our results.

${ }^{3}$ Several papers in the recent IPO literature relate IPO underpricing to the overreaction of investors. Jaggia and Thosar [2004] test the behavioral model proposed by Daniel, Hirshleifer and Subrahmanyam (DHS) [1998], using a sample of IPOs of high-tech stocks that were issued during the technology bubble in the late 1990s in the US. They obtain results that support the
} 
find that the extent of oversubscription is positively correlated with the degree of underpricing. This clearly shows that the excess demand of investors, manifested by the extent of their oversubscription is an important explanatory variable for the greater underpricing of groupaffiliated firm IPOs.

We find that companies controlled by the government are the least underpriced. Although this result is surprising, we discuss it in more detail in section III. On an ex post basis, we find that group-affiliated companies survived better in the stock market than stand-alone companies; however, their long-run stock market performance is worse than stand-alone companies that survived. It appears that the overreaction in the short run around the time of the IPO is reversed over time.

This paper is organized into five sections. The introduction in this section is followed by a brief review of IPOs and business groups and the related literature is discussed in section II. $^{4} \mathrm{~A}$ short description of the Indian primary market is also provided in the same section. The description of the data used for this study and the related statistics are presented in section III. Section IV discusses our empirical results. Concluding remarks are presented in section V.

\section{Literature Review}

\subsection{Group affiliation and firm performance}

The relationship between group affiliation and firm performance has been well documented in the finance, strategy and industrial organization literatures. The broad consensus is that the specific institutional context of the economy plays an important role in determining the merits and demerits of group affiliation. The evidence, so far, suggests that in an environment with a relatively strong institutional infrastructure, enterprises engaged in multiple businesses

behavioral predictions proposed in DHS that investor overconfidence causes overreaction to initial private signals, and the self-attribution bias of investors, results in the initial momentum. The momentum eventually results in long run reversals. This trend is evident in many IPO studies: most IPO papers report initial underpricing followed by long-term underperformance. Using more robust empirical analysis, Purnanadam and Swaminathan [2004], also report evidence in support of the DHS model (as opposed to rational information asymmetry models) to explain IPO underpricing.

${ }^{4}$ To keep the paper more focused, our discussion of the IPO literature is mainly restricted to papers that are related to the certification hypothesis. 
under-perform relative to those that are focused on specific industries (excluding leveraged buy out (LBO) deals) [see, for example, Comment and Jarrell (1995), Berger and Ofek (1995) and Shin and Stulz (1998)]. This "conglomerate discount," interpreted in the context of business groups, would suggest that there are diseconomies associated with group affiliation.

In contrast, in an environment with a relatively weak institutional infrastructure, companies that belong to large, highly diversified groups tend to outperform stand-alone companies. Firms in markets with a poor institutional infrastructure incur higher costs to acquire finance, technology and managerial talent. Group affiliation reduces these costs due to economies of scope and scale, and results in better performance. ${ }^{5}$ On the other hand, if these necessary inputs for the growth of firms are easily available in the marketplace, the positive group effect may disappear. In such cases, group affiliation could be expensive, due to a lack of focus in one particular activity, resulting in underperformance of group-affiliated companies when compared to their stand-alone counterparts. This conclusion would be in line with the "conglomerate discount" hypothesis regarding the industrialized countries, primarily the United States. A recent empirical study by Gopalan, Nanda and Seru [2005] on Indian business groups supports the former conjecture. They find that during conditions of financial distress groupaffiliated companies support each other through intra-group loans to reduce the negative spillover effects of group reputation. However, this support for group-affiliated firms may come at the cost of overall financial performance. These two effects need to be disentangled in order to come to a clear cut conclusion regarding the effects of group affiliation on firm performance.

The other aspect of group affiliation is the relationship to the corporate governance of the firm. Interest in the relationship between group affiliation, corporate governance, and the impact on firm performance has increased with the growing importance of corporate governance issues, both in policy-making and in the academic literature. Many academic papers report that group affiliation is detrimental to firm performance, due to the possible expropriation of funds by the controlling group. The argument is that group companies are prone to poor internal governance, especially when there is excessive control by a family that owns a significant stake. This happens especially when the control rights of the ultimate owners are out of line with their cash flow

\footnotetext{
${ }^{5}$ See, for example, Khanna and Palepu [2000], who relate these differences in the performance of companies to the "substitution" mechanism provided by groups.
} 
rights in a group-affiliated firm. In this context, several papers report evidence of "tunneling" activities - uni-directional, often undisclosed, flows of funds within a group. Typically, these would be from firms where the ultimate owner has low cash flow rights (compared to control rights) to firms where the ultimate owner has high cash flow rights. ${ }^{6}$

Thus, the issue of group affiliation and firm performance is not a straightforward one. This debate is very pertinent in the Indian context, mainly due to the seemingly conflicting results of the Khanna and Palepu [2000] and Bertrand, Mehta and Mullainathan [2002] papers. After comparing the accounting and market-based performance of group-affiliated Indian companies with similar stand-alone companies, Khanna and Palepu [2000] conclude that group affiliation is a positive signal. However, they also point out that the positive relationship holds only for well-diversified and relatively large business groups. Without distinguishing firms based on the extent of diversification, Bertrand, Mehta and Mullainathan [2002] argue that firms affiliated with groups are prone to "tunneling," thus causing a reduction in firm value; consequently, group affiliation could be a negative signal.

However, both these papers, along with similar ones in other countries, examine the ex post performance of firms that are affiliated with groups in comparison with their stand-alone counterparts. If group affiliation is regarded as positive or negative, this ought to be reflected in the pricing of the firm's shares when they are offered for sale to outside investors in the first place. In line with this argument, our study aims to examine the ex-ante perceptions of investors, through the underpricing of IPOs, thus throwing light on the seemingly contradictory prior studies in the context of Indian business groups.

\subsection{The Indian primary market}

The primary market for equity in India gained momentum after the liberalization initiative taken by the government in the early 1990s. Following the improvement in the growth rate of the economy at that time, there were a large number of IPOs, particularly during the period 1990-2004. ${ }^{7}$ Unlike the US market, which is the basis for many IPO studies, the Indian

\footnotetext{
${ }^{6}$ Several studies document such evidence, including those of Classens, Djankov, Fan and Lang [1999]; Classens, Djankov, Lang [2000a]; Claessens, Djankov, and Lang [2000b]; Johnson, La Porta, Lopez-de-Silanes, and Shleifer [2000]; Johnson, and Friedman [2000]; Nam [2001]; Obata [2001], and Baek, Kang and Lee [2006].

${ }^{7}$ Source: Securities Exchange Board of India (SEBI) Public Issue Guidelines.
} 
IPO market has been dominated by retail investors [see Aggarwal (2000)]. During the last fifteen years, the Indian IPO market has undergone many changes that are widely seen to have improved its transparency and efficiency. In particular, the initial years of liberalization, after 1990-91, witnessed a boom in the Indian IPO market. With fewer regulations during this period, many entrepreneurs used the primary market as the main vehicle to raise capital as well as reduce their own holdings. A majority of the IPOs in our sample were issued during the first five years of liberalization (1990-95). The spurt in interest in the equity markets also witnessed several instances of "fly-by-night" entrepreneurs who eroded investor wealth. ${ }^{8}$ During 1995-96, the new securities regulator, the Securities and Exchange Board of India (SEBI), introduced more regulations on IPO pricing and enforced other restrictions on promoters, such as the lock-in period for their holdings. ${ }^{9}$ This resulted in a slump in the IPO market immediately following this period.

To encourage equity participation after the 1995-98 slump, between 1999 and 2000 the SEBI tried to shore up investor confidence by tightening its norms for public issues of equity. Some of the main changes are related to: (1) financial reporting norms; (2) allotment norms; (3) cost/efficiency norms; (4) transparent book building procedures. ${ }^{10}$

Thus, there have been three distinct regimes in the Indian primary market, namely, (1) the immediate post-liberalization regime (1990-1995), (2) the initial regulated regime (1996-2000), and (3) the reformed regulated regime (2001-2004).

\subsection{The IPO Allotment Process}

The allotment process for IPOs in India is quite different from other markets such as those in the United States. In the event of oversubscription, the allotment mechanism in the

${ }^{8}$ The weakness of then-prevailing regulations attracted the SEBI's attention after a major primary market scandal related to an infamous IPO by MS Shoes Ltd in 1995. In the same year, SEBI took some initiatives by appointing the Malegam Committee to recommend appropriate regulations for closer scrutiny of proposed offerings. See Shah and Thomas [2001] and Rao [2002] for more details.

${ }^{9}$ In the parlance of the Indian market and regulations, a "promoter" is the controlling shareholder in the company, and thus, is responsible for its management.

${ }^{10}$ Details of these changes are provided in the more detailed version of this paper available upon request from the authors. 
Indian market is not discretionary. It is based on a formula decided by the company on the advice of the investor banker, but is strictly based on the guidelines issued by the regulator and supervised by the stock exchanges. There have been some changes to the allocation formula over the sample period. ${ }^{11}$ However, the formula has always had the common feature that, in the event of over-subscription, the allotment is made through a rationing mechanism. The rationing system creates an artificial barrier for an investor to have his/her demand filled in full. Since 2000, when the book-building mechanism was introduced in the Indian market, investment bankers managing some, but not all, IPOs have used it. However, the use of book-building still does not rule out the possibility of excess demand and consequent oversubscription. This is particularly true if a large number of potential investors do not participate in this process and the bookbuilding process does not lead to full price-discovery. Furthermore, orders placed in the bookbuilding process are not binding, and could encourage larger players to game the system by not registering their true demand in the book-building process. This is evident in the Indian market, as the oversubscription was not alleviated consequent to the introduction of the book building process. On the contrary, a large allotment scam was reported in 2004. Some investors were prosecuted for creating multiple false accounts to increase their allocations in "hot" issues. ${ }^{12}$ This provides some indirect evidence of the over-reaction hypothesis in the Indian market.

\section{Data and Descriptive Statistics}

\section{$<$ INSERT TABLE 1 HERE $>$}

The data set we assembled consists of attributes of IPOs recorded in the CMIE database on Indian capital markets between the years 1990 and 2004. ${ }^{13}$ The CMIE classifies a company

\footnotetext{
${ }^{11}$ Since the late-1970's, the allotment ratios have been different for various investor categories, such as institutional investors, non-resident Indians, and retail investors, typically with a progressive structure built in: small investors receive a greater proportional allocation than larger investors. This has been since been altered to a straight proportional allocation in each category, in the aftermath of the allotment scam in 2004.

${ }^{12}$ For example, see the article by Sucheta Dalal published in the newspaper, Indian Express, on the $26^{\text {th }}$ April 2004, under the title "Share allotment drama: little to smile about," for a brief description of the allotment scam.

${ }^{13}$ As per the Securities Exchanges Board of India (SEBI) and Prime Database services records, the actual number of public issues raised (including IPOs)in India during 1990 to 2004 was 5667. There is no clear information on the exact number of IPOs among the total public issues. Our sample represents around 52 percent of all public issues issued in India during 1990-2004 and
} 
as affiliated with a group based on an analysis of company announcements and a qualitative assessment of the behavior of the firm in relation to the rest of the group. ${ }^{14}$ Table 1 presents the summary statistics of our sample. We also divide our sample period into three regimes and present a regime-wise classification of our data in the table. This characterization of the different regimes in the IPO market is designed to control for the effect of structural changes in the Indian market on the results from our study. Regime 1 witnessed the highest number of IPOs, while regime 3 had the lowest. Thus, Regime 1 and Regime 3 have been "hot" and "cold" issue periods, respectively, for the Indian market, to use the terminology of Ritter (1984). However, unlike in the US market, where the hot issue period was driven by a boom in specific industrial sectors (e.g. the resources sector), in the Indian market, it was due to structural changes in the political economy, primarily through liberalization.

There are 2,713 IPOs in the fifteen-year period of our study in our data set. During this period, a majority of the IPOs $\left(2,147\right.$, or 79 percent) were issued by stand-alone firms. ${ }^{15}$ The 484 IPOs of private Indian group-affiliated firms represent 18 percent of the total sample. The remaining 82, or 3 percent of the IPOs, are shared between firms affiliated with the government (33, or a little more than 1 per cent) and those affiliated with foreign companies $(49$, or a little less than 2 per cent). The number of IPOs of stand-alone firms is substantially higher than for

includes substantially all the IPOs issued during this period. We also used the PRIME database that contains Indian primary market data for: 1. matching the information available with CMIE; 2. underwriter information; and 3. over-subscription details for the IPOs. To rank the quality of underwriters, we use date from the league tables obtained from ICICI Securities and Finance Ltd.

${ }^{14}$ See the Prowess Users' Manual, Version 2, p.4, for details. Previous studies of group ownership in India such as those of Khanna and Palepu [2000]; Bertrand, Mehta and Mullainathan [2002]; and Gopalan, Nanda and Seru [2005] use the same classification.

${ }^{15}$ Our sample size remains 2,713 in Tables 1, 2 and 3. The sample size changes thereafter based on the availability of data for the independent variables in our analysis. Due to these data gaps, the sample size decreases to between 1,911 to 1,905 in Table 4 and between 1,884 to 1,837 in Table 5. However, we did not find any systematic bias in our reduced sample size. We check this by conducting a simple mean difference test to examine whether the means of independent variables in the reduced sample are significantly different from those of the full sample. We also use propensity matching method as described in Table 5. The reduction in sample size in Table 6 is mainly due to the loss of data points for the calculation of the 36 months window of abnormal returns: the observations in the later years, especially after 2002, do not have 36 months abnormal returns, since our sample ends in 2004. 
IPOs of firms in the other categories. This evidence suggests that most IPOs in our sample have come from new entrepreneurs, after the liberalization of the Indian economy in 1991.

As shown in Table 1, there has been considerable variation in the number of IPOs in each year during our sample period. Most of the IPOs in each category were issued in the first half of the 1990s (Regime 1). This was a boom period for IPOs, largely as a consequence of the opening up of the Indian economy. However, in terms of issue size, the second half of the 1990s (Regime 2) had much larger issues than the first half (Regime 1). The issue size per IPO during Regimes 2 and 3 (post-1996), is substantially higher that of the pre-1996 period (Regime 1). While part of the increase can be attributed to inflation, this broad trend indicates that the IPO market in India became more mature after the SEBI's regulations were introduced, in some cases, and tightened, in others, during 1995-96. As a result, most of the issues made in the post-1996 period were by larger companies, which could pass the close scrutiny of the regulator. However, the number of issues during Regime 3 reduced to a trickle compared to prior years, except for government companies, mainly due to the slump in the world capital markets, following the dot-com collapse in 2000. In the case of government companies, the continued volume of IPOs was due to the privatization program of the government. The average issue size increased in all firm categories over time, indicating the growing maturity of the Indian primary market.

On the average, underpricing is evident across almost all the years in our sample period and across the different categories. Typically, the extent of underpricing is low for firms affiliated with the government. Government-affiliated companies experienced overpricing, on the average, for several years in the total study period. To some extent, this finding is surprising and merits further discussion, especially since several papers report higher underpricing for privatization IPOs in many other countries [For instance, see Menyah and Paudyal (1996), Jelic and Briston (1999) and (2003), Choi and Nam (1998)]. However, on closer examination, Dewenter and Malatesta [1997] find that underpricing is more evident in government privatization in unregulated industries. In our case, many of the privatized companies in India continued to be regulated by the government, since the government still retained a controlling interest in most of them. Hence, our results are consistent with the Dewenter and Malatesta [1997] hypothesis.

Biais and Perotti [2002] try to explain the higher underpricing in the privatization programs using a politically-motivated theory. They argue that underpricing in privatization 
IPOs is often used as strategy to convince middle-class voters to shift their political preferences, toward a market-oriented ideology. In the case of the Indian market, this argument may not hold due to the under-developed nature of the economy and the capital market, where only a small proportion of the electorate have the resources to directly invest in equities. Hence, the political argument may not hold water in the Indian context.

We believe that the lower underpricing in Indian government IPOs may be attributed to two other plausible reasons. First, the size of government IPOs was typically substantially higher than that of other IPOs, as seen in Table 1. In general, as documented in prior studies (see Loughran, Ritter and Rydqvist [1994], which is being regularly updated on Jay Ritter's website), higher issue size is generally correlated with lower underpricing due to the impact of asymmetric information as well as liquidity. Our discussion relating to Table 2 which follows this discussion sheds more light on this issue. Second, the bulk of the privatization program, particularly in Regime 1 consisted of selling a substantial proportion of the issue to government-controlled institutional investors, such as the Life Insurance Corporation of India and the Unit Trust of India, on the basis that a larger number of people, who are claimholders in these entities, would benefit indirectly.

In the case of firms affiliated with Indian group companies, underpricing on the average was as high as 394 per cent in 1999 and came down substantially in 2001 and 2002, and was as low as 17.4 per cent in 2002. In 2001, there was only one IPO and it was overpriced. On the average, stand-alone companies experienced underpricing across all years in the study period. The extent of underpricing, on the average, was the highest in 1999 (689 per cent) and the lowest in 2003 (37.5 per cent). Firms affiliated with private foreign groups experienced record underpricing with the highest recorded in 1991 (1,392 per cent) and the lowest in 1995 (24 per cent). There was a wider variation in other years, but those were typically due to an individual outlier in either direction. Table 1 also reports the average 30-day standard deviation of daily returns in the post-listing period. As shown in the table, the size of the standard deviation is not large enough to explain the extent of underpricing. For instance, the average underpricing for private Indian groups is around 140 per cent; however, the average 30-day standard deviation of return after the listing is only 5.7 per cent. This shows that investor uncertainty cannot fully 
explain the extent of underpricing. Thus, underpricing is likely to be due more to investor overreaction than to any post-listing risk to investors. ${ }^{16}$

\section{$<$ INSERT FIGURE 1 HERE $>$}

The last panel in Table 1 provides summary statistics for all IPOs, across all groups, on a yearly basis. On average, the underpricing in the Indian IPO market during 1990-2004 has been 95.36 percent. This ranks India as the third largest underpriced market among the 39 countries surveyed in the Loughran, Ritter, and Rydqvist [1994], which has been regularly updated. ${ }^{17}$ Figure 1 depicts the information on the number of issues in Table 1 as a time-series plot, with the three regimes demarcated along the X-axis. It is clear from the figure that there has been a significant reduction in the number of IPOs after Regime 1. After the boom period in 1995, the number of IPOs has declined over the subsequent decade, with a minor blip in 2000. This pattern is evident across the various types of groups we analyze: private domestic and foreign group-affiliated companies, government companies and stand-alone companies.

\section{$<$ INSERT FIGURE 2 HERE $>$}

Figure 2 shows the extent of IPO underpricing, as measured by the initial returns for firms in the four categories, over the years. It is interesting to see that the extent of underpricing was much higher across all categories in Regime 1, compared to the other two regimes, with the exception of a spike in Regime 2. However, the spike is due to one IPO in the private foreign group. Overall, as mentioned earlier, it is clear that the extent of underpricing has been declining over our sample period.

\footnotetext{
${ }^{16}$ Chowdhry and Sherman [1996] argue that in many Asian markets the offer price is set prior to the public issue. A low issue price would lead to over-subscription, while a high issue price may result in a failure of the issue. To avoid failure, a risk-averse issuer may underprice the issue. Loughran and Ritter [2002] and [2004] provide two alternative hypotheses, related to underwriters, for severe underpricing. First, when issuers place more importance on hiring reputed underwriters, they become less concerned about avoiding underwriters with a reputation of severe underpricing. Second, issuers may leave more money on the table when they have personal benefits from the underwriters. They argue that there is substantial evidence in the US that underwriters open personal brokerage accounts to allocate "hot" IPOs to executives and related parties of the issuing company. Since underpricing in India is severe in all regimes (including the "cold" issues period), it may not be due to the second hypothesis. Furthermore, unlike in other markets, underwriters in the Indian market do not have any discretion in the allotment of "hot" issues to favored clients.
}

${ }^{17}$ The latest update was in May 2006. 


\section{$<$ INSERT TABLE 2 HERE $>$}

Table 2 summarizes the pooled cross-sectional statistics relating to IPOs during the whole period 1990-2004. This table summarizes the average values of the key variables based on the nature of firm affiliation. Along with average initial return and standard deviation, this table contains the average values for other control variables used in this study. This table also shows that the highest underpricing, on average, across the fifteen year period of our study is for firms affiliated with private foreign groups. Private Indian group-affiliated companies, stand-alone companies and government-affiliated companies follow in hierarchical order. It is interesting to note that the 30-day standard deviation of returns, after listing, also follows the same hierarchical order. However, the magnitudes of the average levels of underpricing are vastly greater than the sizes of the respective standard deviations of returns. This suggests that IPO performance, postlisting, has more to do with investor over-reaction than with the (fundamental) uncertainty of the firm value before the IPO. Firms that are affiliated with large groups attract more investors and the overreaction led to the high listing prices.

We further support this conjecture by providing details of the extent of oversubscription in Table 2. It is clear from the table that there has been excess demand for IPOs in all categories. However, the excess demand, reflected in the extent of oversubscription, is higher among both Indian and foreign group-affiliated firms, compared to stand-alone and government-affiliated firms. On average, Indian and foreign group-affiliated firms got oversubscribed 14 times, which is significantly greater than for stand-alone firms and government-affiliated firms, which were oversubscribed 9 and 8 times, respectively.

The average asset size of the firms in our study varies based on the nature of affiliation. Firms with government affiliation are relatively large in size at the time of the IPO. The IPOs from government-affiliated companies are mostly the result of the government's disinvestment plan. Throughout our sample period, the central and state governments in India divested their stakes in some of the large public sector companies through IPOs. Consistent with the yearly data in Table 1, the underpricing of government-affiliated companies is quite low. These firms also exhibit the lowest standard deviation of returns in the post-listing period. It is surprising to see that the asset sizes of group-affiliated firms (both domestic and foreign) are smaller than those of stand-alone firms. It is generally expected that a venture from an established group should be of greater size than a similar venture from a stand-alone firm. The descriptive statistics 
also indicate that the IPOs of smaller firms are underpriced more often and to a greater degree. Thus, asset size is an important control variable in our study.

Another important variable summarized in the table is the share premium. The share premium represents the difference between the par value of the share and the issue price. ${ }^{18}$ The prospectuses of all IPOs clearly state the share premium for a given IPO, with the practice continuing even today. Although it is the issue price that matters from an economic perspective, there is casual evidence that the share premium, which is widely quoted in the prospectus and other related public announcements by the company, acts on investor psychology. Table 2 shows that the average premium charged by all affiliated firms is higher than that charged by standalone firms. ${ }^{19}$ Given that the oversubscription is high for group-affiliated firms, higher premium may indicate that group-affiliated firms are perceived as more reputable firms by the investors.

The subscription details for IPOs by type of investor - promoters (insiders), the public, institutions, and others - are also summarized in Table 2. The promoters' participation figures clearly show that most of the government-affiliated companies are part of government disinvestment plans. The average promoters' subscription for government-affiliated firms is only 3.7 per cent. The other affiliated firms (private Indian groups and private foreign groups) have a higher level of promoter participation than that of stand-alone firms. The level of public participation in all IPOs is quite similar. However, the level of institutional participation varies based on the nature of group affiliation. Government-affiliated companies, on the average, have the highest level of participation by institutional investors. (Several of the large domestic institutional investors are controlled or tightly regulated by the government.) Stand-alone

\footnotetext{
${ }^{18}$ Par value is an accounting concept indicating a standard value per share. Most Indian IPOs are issued with a Rs. 10 par value, with the "premium" being the excess of the issue price over par.

${ }^{19}$ In our sample there is no significant cross-sectional variation in the offer price. Many studies on the US market exclude from consideration IPOs with very low offer prices. Until a few years ago, during Regime 1 and part of Regime 2, most IPOs in India were at a standard price of Rs 10 (or Rs 100, in a few cases) per share, which was "par." Of course, this price had no economic significance, because significant dilution had occurred, with the result that the number of shares at this price was appropriately adjusted. Indeed, several of the quality issues were made at par in earlier years. Thus, in contrast with the US studies, we segment the IPOs by their asset size rather than by their offer price. It should be noted that we did not include the share premium in our regression analysis as it is part of the issue price. In addition, the issue price is also an ingredient in the calculation of the initial return of the IPO, which is our dependent variable.
} 
companies come next. It is again surprising to see that institutional participation is quite low in both categories of group-affiliated companies. It is generally presumed that higher (or lower) level of institutional investor participation signals a higher (or lower) quality of the firm making the IPO. However, it can also be argued that higher institutional participation is not desirable in the case of group-affiliated companies, from the perspective of the controlling group, since a higher level of participation of institutional investors reduces the group's control over the firm and subjects it to institutional scrutiny. ${ }^{20}$ It may be that greater underpricing may create excess demand, ensuring that the institutions receive smaller allocations, especially since the IPO allotment formula typically has a bias towards small investors.

\section{Results}

\subsection{Preliminary results}

\section{$<$ INSERT TABLE 3 HERE $>$}

Following the preliminary insights from Tables 1 and 2, we extend our analysis to the investigation of the statistical significance of the differences between the key variables across the different categories of firms. Table 3 presents the results of the tests of the mean differences between the key variables. We use analysis of variance (ANOVA) tests to evaluate whether there is any evidence that the means of the various sub-populations differ. However, if there are more than two sub-groups (we have four categories in our analysis), it is inappropriate to compare each pair using a simple $t$-test because of the problem of multiple testing. For this reason, we used the Tukey multiple comparison test, which compares differences between the means, with appropriate adjustments for multiple testing [see Tukey (1977) and Bland and Altman (1995)].

Table 3 tests the differences in the means of each group with those of other groups. For instance, the cell at the intersection of the first row and the third column shows the difference between the means of private Indian group affiliated companies and stand-alone companies for the initial return variables. The $p$-values are shown in the parentheses below each mean difference value. The initial returns or the extent of underpricing between group-affiliated companies, both private Indian and foreign, and stand-alone companies is significantly different. The positive mean difference value indicates that the domestic group companies' mean value for

\footnotetext{
${ }^{20}$ In many cases, institutional investors obtain a seat on the boards of companies where they have a stake.
} 
initial returns is higher than for stand-alone companies. Likewise, the mean difference values can be interpreted for other variables, and used in comparisons between other pairs of groups. The initial return of government-affiliated companies is not statistically different from that of companies in other categories. However, the asset size is significantly different from that of other groups. Table 3 shows that, in terms of asset size, the mean difference value between groupaffiliated companies and their stand-alone counterparts is not statistically significant. The issue size of domestic group-affiliated companies is larger than that of stand-alone companies and smaller than that of government-affiliated companies. The share premium charged by domestic group-affiliated companies is higher than that charged by stand-alone firms, and smaller than that charged by foreign group-affiliated companies.

The difference between the means of the proportions of promoter participation is not significantly different between group-affiliated and stand-alone companies. However, there is a highly statistically significant difference, in this regard, between group-affiliated companies and government-affiliated companies. The same results hold for public participation. The finding regarding institutional investor participation is also not that surprising, as discussed in section III. The only mean difference value that is statistically significant is between private Indian groupaffiliated companies and stand-alone companies. The level of institutional participation of investors for stand-alone companies is higher than that for domestic group-affiliated companies, which is in line with the discussion in the previous section.

The mean difference test shows that the extent of oversubscription for the Indian and foreign group-affiliated firms is significantly higher than for stand-alone and governmentaffiliated firms. This again confirms investors' excess demand for the IPOs of group-affiliated firms.

In summary, the results of tests of differences in the means provide strong evidence that group-affiliated firms (both domestic and foreign) are quite different from stand-alone companies and government-affiliated companies in several respects.

\subsection{Regression results}

\section{$<$ INSERT TABLE 4 HERE $>$}

Table 4 presents regression results for the initial returns from IPOs to help examine the causal relationship between the extent of underpricing and firm characteristics. We consider six sets of independent variables. The first set consists of firm characteristics such as issue size and 
asset size. ${ }^{21}$ The second set consists of the group affiliation dummies for three of the four categories we have defined. The third set of characteristics relates to the industry dummies for three of the four industry sectors identified - banking, other financial services, manufacturing, and other services. (The "other services" category of industries does not have a dummy variable attached to it). The fourth set of variables is the dummies for the three regimes (with Regime 3 being excluded) defined earlier that sub-divide our time series. The fifth set is the investor dummies for promoter, public and institutional participation. (The "others" category of investor participation is excluded). The dummy variable takes the value 1 for the corresponding category, and 0 , otherwise. For instance, for the dummy variable defining government companies, the value is 1 for the corresponding data related to government companies and 0 for the remaining categories. The last set consists of the extent of over-subscription and the quality of underwriters as the independent variables.

We estimate eight regressions for different sets of independent variables, in order to assess the incremental impact of each set of variables on the extent of underpricing. Even though asset size varies significantly across the different categories we have defined, we find no evidence of any significant relationship between asset size and the extent of underpricing. However, the coefficient of the issue size of the IPO is negative and significant. This implies that the larger the issue size, the lower is the underpricing, which is in line with the results of other studies (See, for example, Loughran, Ritter and Rydqvist (1994) and the references cited therein). The domestic group dummy is positive and highly significant in all four regressions. Thus, after controlling for other factors, we find that being part of a private Indian group influences the extent of underpricing in a positive manner. The same positive relationship for the extent of underpricing holds for firms affiliated with private foreign groups. The coefficients for the industry dummies are all insignificant. Thus, underpricing is seen across all industry categories and it is not industry-specific in terms of its relative importance. Of course, it is possible that our industry classification is too coarse to detect such effects, particularly if they vary over time. We could not examine this issue in greater detail due to the paucity of detailed industry classification data (along the lines of data in the industrialized countries).

${ }^{21}$ The correlation between issue size and asset size is quite low (0.021). Hence, there is no serious issue of potential multicollinearity here. Also, it should be noted that we dropped the age of the firm as an independent variable, since it is highly correlated with asset size. 
Our results relating to the variations across regimes are reported in Regressions 3 and 4 in Table 4. The coefficient for Regimes 2 is negative and significant. This indicates that firms that undertook IPOs during Regime 2 were, on the average, less underpriced compared to the firms that issued equity during Regime 1 and Regime 3. Thus, the tighter regulations introduced in Regime 2, as discussed in section II.C, had an effect on IPO pricing. Contrary to our expectation, based on the prior literature (see, for example, Loughran, Ritter and Rydqvist (1994) and the references cited therein), we find that promoter participation in the IPOs does not influence the extent of underpricing. However, institutional investor participation and public participation reduces the extent of underpricing. This indicates that institutional interest signals firm quality and improves the valuation. However, our result with regard to institutionally-affiliated companies runs counter to the conclusion of Hamao, Packer and Ritter [2000] for the Japanese market. They find a positive relationship between institutional affiliation and the degree of underpricing. It may be that the links within groups are stronger in Japan during the 1990s than in India during the period of our analysis

\subsubsection{Testing the over-reaction hypothesis}

\section{$<$ TABLE 5 HERE $>$}

The evidence so far shows that, the traditional theories of information asymmetry, similar to the Dewenter et.al (2001) tradeoff hypothesis between visibility and opaqueness as a mechanism for underpricing of group-affiliated firms, for the Japanese market, may not fully explain the extent of underpricing in the Indian market. This is mainly due to the higher underpricing of foreign group-affiliated firms. We now turn our attention to behavioral explanations for understanding the higher underpricing of group affiliated firms. A recent paper by Purnanandam and Swaminathan [2004] argue that, in the US market, behavioral explanations fit better than traditional, rational models to explain initial underpricing and subsequent underperformance of IPOs. In particular, they provide evidence in support of the predictions of DHS that stock prices initially overreact to information, due to investor overconfidence that gathers further momentum due to the self-attribution bias of investors. The momentum finally results in reversal after information is fully revealed. Although Purnanandam and Swaminathan [2004] point out that overconfidence enters into picture due to the excess demand of investors who are most interested in IPOs, they could not test their conjecture for lack of data regarding the excess demand of investors. 
We are fortunate to be able to obtain data on this excess demand - the extent of oversubscription of each IPO. With this data, we are able to measure the excess demand of investors, and thus provide a proxy for overconfidence and subsequent overreaction. The over-reaction hypothesis asserts that the excess demand results from the attention that group-affiliated firms attract in relation to stand-alone firms (perhaps due to their respective reputations, for example), and creates uncertainty about the allocation that investors will obtain from the IPO. This holds especially when the allocation process is rationed accordingly to a well-publicized formula, as in the case of Indian market. The higher the extent of over-subscription, the more severe will be the shortage in the investors' allocation. In order to reach their desired allocation, investors will be forced to buy the stock after listing in the stock market, thus driving up the price. This results in greater underpricing of the IPO, as measured by its initial return. Thus, underpricing and oversubscription should be positively related, according to the over-reaction hypothesis.

Regression 5 uses the extent of over-subscription, after controlling for all other variables in Regression 4, as a variable to explain underpricing in IPOs. Consistent with the overreaction hypothesis, we show that the extent of subscription has a positive and highly significant coefficient, for both domestic and foreign group-affiliated firms. This confirms that the overreaction hypothesis provides a better explanation than the tradeoff hypothesis proposed by Dewenter et al. (2001): due to higher over-reaction (estimated by higher subscription) for group affiliated firms, there is higher underpricing compared to the stand-alone firms.

It should be noted that adding the extent of oversubscription as an independent variable may lead to problems of reverse causality. On the one hand, excess demand measured by the extent oversubscription may drive the price and hence the initial returns. On the other, the expectation of high initial returns may lead to oversubscription, as Koh and Walter [1989] argue. The standard method of addressing problems of reverse causality is the identification and estimation (in the first stage) of an instrumental variable for oversubscription. We tried various instrumental variables and found that firm size at the time of the IPO is not only highly correlated with the extant of subscription but also is exogenous. We report the results for the (second stage of the) two-stage least square regression under Regression 8 in Table 4. This regression uses firm size at the time of IPO as the instrumental variable. As shown in the table, the implication of this regression are consistent with that of the other regressions: the extent of subscription is positively correlated with the initial return. 


\subsubsection{Underwriter quality and underpricing}

There is substantial evidence that the quality of the underwriter partly explains the degree of underpricing in IPOs in many countries. It has been found that the underwriter's reputation generally reduces the extent of underpricing for IPOs and thus underwriters, similar to groups in our context, may provide certification benefits. Although there are no well-defined measures of underwriter quality in the Indian market, we define the top ten underwriters (in terms of the value underwritten) from the league tables for each of the fifteen years, as reputable underwriters. We also use top five as a variant of this definition. The results are presented under Regressions 6 and 7 respectively. Contrary to the existing evidence, we find that underpricing is greater if the issue is managed a reputed underwriter. However, the statistical significance of this finding is relatively weak (significant at the $10 \%$ level), and it is not significant when the definition is changed to the top five underwriters. This result also shows that better reputation may create greater over-reaction in the Indian market.

It should be noted that the adjusted R-squared reported is quite low in Table 4, ranging between 4 percent to 6.5 percent. This indicates that the independent variables, while statistically significant, explain only a small proportion of the variance in the initial returns. However, a low adjusted R-squared is a common feature in many IPO-related studies, perhaps due to structural shifts that are not captured in the use of combined time-series, cross-sectional data. For example, a related certification based paper by Carter, Dark and Singh [1998], reports much lower adjusted R-squared ranging between 2 to 4 percent.

\subsubsection{Sample Selection Issues}

As noted in our discussion of Table 1, the degree of underpricing, on average, among the four group categories has declined over the years. The question arises as to whether this secular decline is due to changes in the cross-sectional composition of the categories over the years. We try to explicitly examine this issue of changes in the composition of the four categories over the years, across the three regimes, notwithstanding the substantial variation in the sizes of the sample over the years. Econometrically, this amounts to testing whether the degree of underpricing of the IPOs of individual firms is correlated with the characteristics of each group category. We need to examine whether ignoring the correlation between firm characteristics and the characteristics of each group category in estimating the relationships documented in Tables 3 and 4 would lead to biased estimates of the quantitative effects of firm characteristics on the 
level of underpricing. We implement these tests, by creating characteristics for each group category, for each of the corresponding firm characteristics, by calculating the average value of the characteristics for all firms in that category. With these variables for the characteristics of the group categories, we aim to capture the potential group effects. Although not reported in the paper, we find the coefficients of the group characteristics variables to be statistically insignificant. This indicates that there was not much cross-sectional variation among the categories in terms of their group characteristics over time, and that the attribution of underpricing to firm characteristics seen in Tables 3 and 4 is robust.

However, averaging the group characteristics may mask the sample selection bias because the characteristics of a firm may dictate into which category it falls. In other words, if the characteristics of firms that are in the stand-alone category are different from those of the group-affiliated firms, the differences in underpricing may be driven by such ex ante differences and create an endogeneity bias. We verify the robustness of the cross-sectional variation in group characteristics by using the propensity score matching method. Under this method, we match the sample based on the propensity for underpricing, rather on the group classification. IPOs with underpricing more than (less than or equal to) $0 \%$ are defined as underpriced (not underpriced). ${ }^{22}$ We calculate the propensity scores of each observation in our sample by running a logistic regression with the propensity of underpricing as the dependent variable ( 0 : no underpricing/ 1 : underpricing). The independent variables are the group characteristics defined by the variables used in Table 4. Consequently, firms that have equal propensity to underprice will be matched, irrespective of their affiliation. Thus, the propensity score-based matching eliminates the systematic differences between the groups.

We then divide the sample into quintiles, based on their propensity scores and regroup the firms in each quintile into group-affiliated and non-group affiliated firms based on group characteristics. We report the $t$-values based on non-parametric Wilcoxon rank sum test for each quintile for all group characteristics in Table 5 . We expect that the t-values should be insignificant, if there had been cross-sectional variation in the average group characteristics over

\footnotetext{
${ }^{22}$ We use two alternative measures of underpricing, using $5 \%$ and $10 \%$, as the cut-off for measuring underpricing to test the robustness of our procedure. The results reported here are for the $0 \%$ cut-off and are qualitatively similar to those obtained with other definitions of underpricing.
} 
time. However, if the group characteristics had been relatively stable, the $t$-values of the mean differences should be significant. The results in Table 5 show that the group-affiliated firm characteristics are significantly different from those of stand-alone firms, even after propensity score matching. This confirms that the characteristics of firms in the different categories remained relatively stable over our sample period.

\subsection{Post-IPO performance}

\subsubsection{Firm survival analysis}

\section{$<$ INSERT TABLE 6 HERE $>$}

We further investigate the post-IPO performance of firms in the various categories to gain some insight into the long term survival and stock market performance of the firms that issued an IPO. This analysis is useful in comparing our results with those in the Dewenter et.al. [2001] study, to understand the long term effects of group affiliation along with the short term effects.

We estimate the success probability of a given firm based on its category of affiliation by using an ordered probit model. We use the current listing band of a given IPO in the Bombay Stock Exchange in India (BSE) as a proxy for the long-run success of the IPO. The BSE classifies all listed stocks into different quality bands, namely, A, B1, B2, C and Z groups. ${ }^{21}$ Shares that are classified in the A band are generally the large, liquid, blue chips of the Indian stock market. B1, B2 and C follow in the quality hierarchy from high to low. The firms that are classified as $\mathrm{Z}$ are usually failures. These companies are classified as such either because they declared bankruptcy or because they violated the listing norms of the BSE, and were, therefore, suspended from trading. Thus, the BSE classification acts as a barometer for a firm's success in the Indian stock market, somewhat akin to a rating from a credit rating agency. The ordered probit model estimates the probability of failure by taking values 1 to 4 for A, B1, B2 and Z categories respectively. ${ }^{23}$

The results are presented in Table 6 . We used both private Indian and private foreign group dummies that take the value 1 if the firm is affiliated with a private domestic or foreign group, respectively, and 0 otherwise. Similar to the regression models in Table 4, we report

\footnotetext{
${ }^{23}$ We also ran the probit model with just three classes, A, with a value of 2, B1 and B2, in one class with a value of 1 , and $Z$ with a value of 0 . The results are qualitatively similar, although less sharp than the ones reported here.
} 
results using four different models in order to assess the incremental impact of each set of variables on the probability of failure or success of firms. The negative, statistically significant, coefficients for both the domestic and private foreign group dummy variables, which are reported for all four models, indicate that the failure probability for a firm affiliated with either a private domestic or foreign group is lower than that for a stand-alone firm. In other words, if a firm is affiliated with either a private domestic or foreign group, the probability of the firm listing in the lower bands is low. The results also indicate that, on the average, firms that experienced higher underpricing in their IPOs have a lower probability of survival. ${ }^{24}$ The size of the company, measured by assets, and the extent of promoter or institutional participation in the IPO is also negative and significant. This indicates that large firms survive better than small firms. This result is consistent with the IPO literature [See Jain and Kini (1999) and Howton (2006)]. Also, IPOs issued during Regime 1 failed more often than those issued during the other two regimes. This is consistent with the opportunistic actions of "fly-by-night" entrepreneurs in Regime 1 as described in section II.C. ${ }^{25}$ This may be due to the fact that very few firms ventured into the capital market during this period, and those that did so tended to be the robust ones, perhaps due to the closer scrutiny of the regulator and the more demanding market conditions. There are no patterns in the relationship between the nature of industry affiliation and the survival odds, except in the banking industry. All industry affiliations have equal chances of failure relative to the banking sector, which seems to have a lower probability of failure. Again, this may be due to the additional requirement of scrutiny by the banking regulator, in addition to the securities regulator. We find that the extent of underpricing is inversely related to the probability of failure. This indicates that firms that registered higher underpricing survive better than firms that experienced lower underpricing. This is consistent with the results in Table 4:

\footnotetext{
${ }^{24}$ We did not use issue size as an independent variable, as one would expect its effect to wear off over time.

${ }^{25}$ It should be noted that companies that went public in 1991 have a maximum of 14 years in which to end up in the Z-group, whereas, the IPOs issued in 2004 have barely a few months to fail. In order to tackle this issue, we also ran the model using only Regime 1 data. The results are qualitatively similar to the models in Table 5. All the coefficients and their significant levels are similar to the values reported in Table 5.
} 
group affiliated firms experienced higher underpricing. Thus, underpricing seems to be more an over-reaction to group affiliation than signaling higher risk, defined in terms of odds of survival.

Stand-alone companies represent around 80 percent of IPOs issued in the Indian market, while group-affiliated companies represent only 18 percent of the IPO market. However, these numbers need not be reflected in the probability of success of any individual firm, as measured by the changes of getting listed in the A and B1 bands. However, as shown in Table 2, among the companies that failed (ended up in the Z-group), 82 percent belong to stand-alone companies. Also, as shown earlier in Tables 1, 2 and 3, the size of domestic group-affiliated companies is not significantly different from that of stand-alone companies. The ordered probit analysis reinforces this conclusion in terms of the probability of success: size is not significant for the likelihood of success of firms making the IPO. Thus, after controlling for other variables that might affect their performance, both private domestic and foreign group-affiliated companies survived better in the post-IPO period than stand-alone companies. The reason for better survival odds for group companies could be due to the implicit contracts between group firms to help each other, in a weak legal system, in the event of distress [see Bull (1987) and Shleifer and Vishny (1997)]. Gopalan, Nanda and Seru [2005] also found evidence that Indian business groups tend to support each other through intra-group lending in cases of financial distress. ${ }^{26}$ They concluded that these supporting actions serve to safeguard the group's reputation in the capital market. Our survival analysis partially supports this argument. Group firms might survive better, post IPO, due to this supporting mechanism, which is not available to stand-alone companies. ${ }^{27}$ However, the above evidence of greater survival odds of group firms is not conclusive. We explore the reasons for better survival at greater depth in the following section using additional data on intra-group lending and borrowing.

\subsubsection{Intra-group Lending and Borrowing}

${ }^{26}$ There is anecdotal evidence that this happens very often. In a well-publicized episode involving Tata Finance Ltd., the group companies of the Tata group provided financial assistance to bail it out of financial distress in 2003 .

${ }^{27}$ Since the firm classification is based largely on firm performance, size and liquidity, it is possible that some of the effects we document could, at least partly, be due to liquidity effects. We are unable to examine this issue in detail due to the lack of microstructure data - trading volume, bid-offer spreads etc. - for our sample. We believe that the firm size proxies for these liquidity effects, at least partly. 
We lend further credence to the hypothesis of group support for survival of groupaffiliated firms by examining the intra-group lending and borrowing in the Indian family business groups. The main mechanism of intra-group support for companies in a business group is through the provision of financial support for each other. This may occur because one group company has surplus resources, while another has a deficit, and the financing is an arms-length transaction at market interest rates. Alternatively, it may be because the controlling group has different cash-flow rights in the two companies and derives a benefit from such a transaction, which is not at market rates. In either case, such financing provides co-insurance for group firms at rates that are in line or out of line with market conditions. One of the main reasons attributed to better survival of group firms is the co-insurance that is available in a business group. The coinsurance hypothesis states that business groups help each other in the case of adverse conditions and thus survive better than non-group firms [see Khanna and Yafeh (2005]. Thus, the coinsurance hypothesis suggests that there should be intra-group bi-directional flows based on necessity. For instance, if a group firm makes a loss, then it should borrow more from other firms in the group with a surplus, and similarly, a firm that makes profits should lend more to other firms that are in need of funds.

We were able to obtain data on these loans to and from group firms for the years 2000 until 2005. ${ }^{28}$ We first test the differences between loans to group firms (LTG) and borrowing from group firms (BFG) for profit- versus loss-making firms. We then examine the extent to which LTG and BFG can be explained by the profit or loss made by each firm. .

\section{$<$ INSERT TABLE 7 HERE $>$}

The results are arranged in two panels in Table 7. In Panel A, all the group firms are segregated as profit- or loss-making firms on a yearly basis, with the last column reporting aggregate profit or loss for all years between 2000 and 2005. We then test for the differences for the LTG and BFG variables between the two sets of firms for each year and for the whole period. The results show that there is a significant difference between profit making and loss making firms based on the loans given to the group firms (LTG): profit- making firms lend significantly more than loss-making firms. This finding is consistent with the co-insurance hypothesis. In the

\footnotetext{
${ }^{28}$ Unfortunately, we were not able to get the data for the total sample period mainly due to the non-availability of such data for a large proportion of the firms in our sample.
} 
case of borrowing (BFG), the aggregate borrowings of loss-making firms are higher than for profit-making firms. However, unlike lending, the difference is not statistically significant.

We test this relationship more formally using regression analysis. Panel B reports regression results examining the relationship between the extent of lending (borrowing) and the operational performance of group firms, measured by operating income. We also use firm age, size (measured as total assets) and financial health (measured as solvency ratio) as the control variables. We test lending (LTG) and borrowing (BFG) separately. A positive coefficient for operating income in the lending regression confirms more lending by profitable companies. Similarly, a negative coefficient for operating income in the borrowing regression confirms more borrowing by loss making firms. However, similar to panel A, the results in the case of borrowing are not statistically significant. These results suggest that when firms have surplus resources, they are likely to lend them to group companies that need assistance. However, when firms have deficits, they may not obtain help from group companies, but perhaps they need to go outside the group, in addition. All in all, our intra-group financing results support the conjecture that co-insurance exists in Indian family business groups. These results can explain why group firms survive better than stand alone firms, since such intra-group assistance may not be available for non-group firms.

\subsubsection{Long-run performance of IPOs}

\section{$<$ INSERT TABLES 8 and 9 HERE $>$}

We next analyze the long-run return performance of IPOs for firms in the various categories discussed earlier. The results are reported in Tables 8 and 9. Consistent with the IPO literature relating to the evidence in other countries [see, for example, Ritter, 1991], we find that the average long-run return performance of firms, post IPO, is significantly negative. This has been consistently true for different horizons - 12, 24 and 36-month windows - indicating the systematic over-optimism of the investors regarding the performance of new investment opportunities. ${ }^{29}$ This consistent with the behavioral theory of initial overreaction and subsequent

\footnotetext{
${ }^{29}$ See Ritter [1991], Levis [1993] and Aggarwal, Leal and Hernandez [1993], for US, UK and Latin American markets respectively. Also, it should be noted that our sample size for the long term analysis is smaller compared to the short-term and IPO analyses, because our sample period does not completely cover the different horizon periods in all cases. The sample sizes are reported in the tables.
} 
reversals proposed by many authors including, Barberis, Shleifer and Vishny [1998], DHS, and Hong and Stein [1999].

In Table 8, we report the long-run return performance statistics for our data set. We use both the Buy-and-Hold Abnormal Return (BHAR) and the Cumulative Average Abnormal Return (CAAR) measures for our long-run performance analysis. These are the standard metrics used in the IPO literature and represent different ways of defining the return: BHAR is the riskadjusted return based on buying at the beginning of the period and selling at the end, taking into account any intervening distributions, while CAAR is the cumulative average return assuming, compounding in each period [see, for example, Brav, Geczy, and Gompers (2000)]. Among the different firm categories we had defined earlier, we find that the magnitude of negative long-run stock market performance is greater for private foreign groups and private Indian groups than for stand-alone companies. These differences between group companies and stand-alone companies are statistically significantly different from zero for both these categories, over all the three horizons defined earlier, and also using both measures of return performance. This can be explained by the higher underpricing of group-affiliated firms. The subsequent long term reversals, as predicted in the behavioral finance literature, imply that higher underpricing should also result in greater reversal.

However as indicated in Table 9, which reports whether there is any significant variation in long-run performance across the various categories in our sample, shows that there is no significant difference in long-run performance between the four groups. There appear to be no clear differences among the post-IPO return measures that are statistically significant. This confirms the conjecture that long-run underperformance, similar to other markets, is more a general phenomenon across all types of firms. ${ }^{30}$ Thus, the negative performance of firms affiliated with domestic and foreign groups is not that significant on a relative basis.

${ }^{30}$ There is a long-standing debate on mis-measurement issues related to the methodology used to calculate long-run performance. For instance, Brav, Geczy, and Gompers [2000] show that the choice of performance measurements directly determines both the size and the power of statistical tests. However, we believe that the magnitude as well as the consistency of our results, for different horizons and for both measures of return performance, is striking, notwithstanding this theoretical argument. 
We also report raw buy and hold returns for the 12, 24 and 36 month windows. The raw returns indicate that the performance of all IPOs over all three horizons is good, in absolute terms, with returns ranging between 51 per cent and 98 per cent, per annum, for all groups. However, when adjusted for market returns over the corresponding horizons, the excess returns turn out to be poor. This is due to the fact that as in other markets, IPOs are timed to be made in "hot" market conditions. This is consistent with the behavioral explanation: the windows of opportunity hypothesis of Ritter [1991] and Loughran and Ritter [2002]. This hypothesis suggests that IPOs are timed when the equity of the issuer may be overvalued. It is also in line with the Miller (1977) argument that investors who are most optimistic will be the initial buyers.

\section{Conclusion}

We document the results of a comprehensive study of the Indian IPO market focusing on the effect of group affiliation on the initial performance in the post-listing market. We use a relatively large sample of 2,713 IPOs that were issued in India between 1990 and 2004 to test whether group affiliation affects the extent of underpricing. Similar to Dewenter et.al. [2001], we test two competing hypotheses on the relationship between group affiliation and the extent of underpricing. The "certification" hypothesis asserts that, in less developed capital markets, groups form internal capital markets to help member companies in the case of financial distress. Thus group affiliation acts as a positive signal, resulting in lower underpricing than for standalone companies. On the other hand, the "tunneling" hypothesis asserts that, due to excessive control of the family on group companies, the controlling family may expropriate the future cash flows of the affiliated companies. Thus, group affiliation acts as a negative signal, consequently resulting in greater underpricing. We find that underpricing is greater for firms affiliated with groups. Our results hold for both domestic and multi-national private foreign groups that are presumed to be more transparent; hence, we cannot attribute underpricing solely to the tunneling effect or complexity of group affiliation as argued by Dewenter et al. [2001].

We, therefore, extend our analysis beyond the framework of Dewenter et al. [2001] to uncover the possible reasons for higher underpricing in both domestic and private foreign 
groups, by examining the post-IPO success of the firms. Our survival analysis indicates that group-affiliated companies survive better than stand-alone companies. We conjecture that this could be due to a better support mechanism for group-affiliated companies than that for their stand-alone counterparts in the case of financial distress, as argued by Gopalan, Nanda and Seru [2005], since groups try to preserve their market reputation. Thus, group affiliation acts as a positive signal to the market. However, our long-run IPO performance results, measuring the stock market performance of the firms, are consistent with the results in other countries: in the long run, firms that were underpriced in their IPOs experience negative performance over time. We reconcile these two findings by arguing that investors overreact at the time of the IPO to group reputation with the reaction being gradually reversed over time. Using data on the extent of over-subscription as a proxy for excess demand, we confirm that over-reaction (measured using excess demand for IPOs) is positively related to underpricing.

The greater failure rate of standalone companies in the capital market raises concerns over the allocation of capital and the development of entrepreneurs in emerging economies. In the future, many issues can be addressed based on our study. Some interesting directions are indicated by these questions: 1) Are family business groups optimal organizational structures in economies with relatively undeveloped capital markets? 2) Do group companies hinder entrepreneurial growth? 3) What steps can be taken to reduce investor overreaction to IPOs? 


\section{References}

Aggarwal, R. (2000). India IPO market. Working paper. World Bank working paper series.

Aggarwal, R., Leal, R., and Hernandez, L. (1993). The after-market performance of initial public offerings in Latin America. Financial Management, 22, 42-53.

Barberis, N., Shleifer, A. and Vishny, R. (1998) "A model of investor sentiment" Journal of Financial Economics, 49, 307-343.

Barry, C.B., Muscarella, C. J., Peavey, J., and Vetsuypens, M. (1990). The role of venture capital in the creation of public companies. Journal of Financial Economics, 27, 447-471.

Baek, J.S., Kang, J.K., and Lee.I. (2006). Business groups and tunneling: evidence from private security offerings from Korean Cheabols. Journal of Finance, 61, 2415- 2449.

Beatty, P.R. (1989). Auditor reputation and the pricing of initial public offerings. The Accounting Review, 4, 693-709.

Berger, P. G., and Ofek, E. (1995). Diversification's effect on firm value. Journal of Financial Economics, 37, 39-65.

Bertrand, M., Mehta, P., and Mullainathan, S. (2002). Ferreting out tunneling: An application to Indian business groups. Quarterly Journal of Economics, 117, 121-147.

Biais, B., and Perotti, E. (2002). Machiavellian privatization. American Economic Review, 92, 240-258.

Bland, J.M., and Altman, D.G. (1995). Multiple significance tests: the Bonferroni method. British Medical Journal, 310, 170.

Brav, A., Geczy, C., and Gompers, P. (2000). Is the abnormal return following the equity issuance anomalous? Journal of Financial Economics, 56, 209-249.

Bull. C. (1987). The existence of self-enforcing implicit contracts. Quarterly Journal of Economics, 102, 147-160.

Carter, R., Dark, R., and Singh, A. (1998). Underwriter reputation, initial returns, and the longrun performance of initial public offering stocks. Journal of Finance. 53, 289-311.

Chemmanur,T.J., and Paeglis, I. (2005). Management quality, certification, and initial public offerings. Journal of Financial Economics, 76, 331-368.

Choi, S.D., and Nam. S.K. (1998).The short-run performance of IPOs of privately- and publiclyowned firms: International evidence. Multinational Finance Journal, 2, 225-244. 
Chowdhry, B., and Sherman, A. (1996). International differences in oversubscription and underpricing of IPOs. Journal of Corporate Finance, 2, 359- 381.

Claessens, S., Djankov.S., Fan.J., and Lang, L. (1999). On expropriation of minority shareholders: evidence from East Asia. Working paper, accessed at http://ssrn.com/abstract=202390.

Claessens, S., Djankov.S., and Lang, L. (2000a). The separation of ownership and control in East Asian corporations. Journal of Financial Economics, 58, 81-112.

Claessens, S., Djankov.S., and Lang, L. (2000b). East Asian corporations: heroes or villains? World Bank Discussion Paper, No. 409.

Comment, R., and Jarrell, G.A. (1995). Corporate focus and stock return. Journal of Financial Economics, 37, 67-87.

Daniel, K., Hirshleifer, D., and Subrahmanyam, A. (1998). Investor psychology and stock market under- and over- reactions. Journal of Finance, 53, 1839-1886.

Demstez, H., and Lehn, K. (1985). The structure of corporate ownership: causes and consequences. Journal of Political Economy, 93, 1155-1177.

Dewenter, K., and Malatesta, P. (1997). Public offerings of state-owned and privately-owned enterprises: An international comparison. Journal of Finance, 52, 1659-1679.

Dewenter, K., Novaes, W., and Pettway, R.H. (2001). Visibility versus complexity in business groups: evidence from Japanese keiretsu. Journal of Business, 74, 79-100.

Faccio, M., Lang. L, and Young. L. (2001). Expropriation and Dividends. American Economic Review, 91, 1-25.

Faccio, M., and Lang. L. (2002). The Ultimate Ownership of Western European Corporations. Journal of Financial Economics, 65, 265-395.

Gopalan, R., Nanda, V., and Seru, A. (2005). Reputation and Spillovers: Evidence from Indian business groups. Journal of Financial Economics, forthcoming,

Hamao,Y., Packer. F., and Ritter, J.R. (2000). Institutional affiliation and the role of venture capital: evidence from initial public offerings in Japan. Pacific Basin Finance Journal, 8, 529558.

Hong, H., and Stein.J,C. (1999). A unified theory of underreaction, momentum trading and overreaction in asset markets. Journal of Finance, 54, 2143-2184. 
Howton. S. (2006). The effect of governance characteristics on the state of the firm after an initial public offering. The Finance Review, 41, 419-433.

Jaggia, S., and Thosar, S. (2004). The medium-term after market in high-tech IPOs: Patterns and implication. Journal of Banking and Finance, 28, 931-950.

Jain, B., and Kini, O. (1999). The life cycle of initial public offerings. Journal of Business Finance and Accounting, 26, 1281-1307.

Jelic, R., and Briston, R. (1999). Hungarian privatisation strategy and financial performance of privatised companies. Journal of Business Finance and Accounting, 26, 319-1357.

Jelic, R., and Briston, R. (2003). Privatisation initial public offerings: The Polish experience. European Financial Management, 9, 457-484.

Johnson, S., La Porta, R., Lopez-de-Silanes, F., and Shleifer, A. (2000). Tunneling. American Economic Review: Papers and Proceedings, 90, 22-27.

Johnson. S., and Friedman. (2000). Tunneling and propping. Working Paper, MIT.

Khanna, T., and Palepu, K. (1997). Why focused strategies may be wrong for emerging markets? Harvard Business Review, 75, 41-51.

Khanna, T., and Palepu, K. (2000). Is group membership profitable in emerging markets? An analysis of diversified Indian business groups. Journal of Finance, 55, 867-891.

Khanna, T., and Yafeh, Y. (2005). Business groups and risk sharing around the world.

Journal of Business, 78, 301-340.

Levis, M. (1993). The long run performance of initial public offers: the UK experience. Financial Management, 22, 28-41.

Loughran, T., and Ritter, R. J. (2002). Why don't issuers get upset about leaving money on the table in IPOs? Review of Financial Studies, 15, 413-443.

Loughran, T., Ritter, R.J., and Rydqvist. K. (1994). Initial public offerings: International insights. Pacific-Basin Finance Journal, 2, 165-199. The latest update is sourced from: http://bear.cba.ufl.edu/ritter/publ_papers/Int.pdf

Menyah, K., and Paudyal, K. (1996). Share issue privatisations: The UK experience, in Empirical Issues in Raising Equity Capital, M. Levis (ed.), Amsterdam, Elsevier Science.

Miller. E. (1977). Risk, uncertainty and divergence of opinion. Journal of Finance, 32, 11511168. 
Nam, S.W. (2001). Business groups looted by controlling families, and the Asian crisis. ADB Institute Research Paper, series No. 27.

Obata, S. (2001). Pyramid groups, financial distress and investor protection. Working Paper, Harvard University.

Purnanandam, A.K., and Swaminathan.B (2004). Are IPOs Really Underpriced. Review of Financial Studies, 17(3), 811-848.

Rao, K.S. (2002). Stock market. Alternative Economic Survey, 2001-2001.

Ritter, J.R. (1984). The hot issue market of 1980. Journal of Business, 57, 215-240.

Ritter, J.R. (1987). The cost of going public. Journal of Financial Economics, 19, 269-281.

Ritter, J.R. (1991). The long-run performance of initial public offerings. Journal of Finance, 46, $3-27$

Shin, H., and Stulz, R. (1998). Are internal capital markets efficient? Quarterly Journal of Economics, 113, 531-552.

Shah. A., and Thomas.S. (2001). Policy issues in the Indian securities market. Working Paper No. 106, Stanford University.

Shleifer, A., and Vishny, R. W. (1997). A survey of corporate governance. Journal of Finance, $52,737-783$.

Tukey, J.W. (1977). Exploratory data analysis. [Reading MA]: Addison-Wesley Publishers.

Welch, I. (1989). Seasoned offering, imitation costs, and the underpricing of initial public offerings. Journal of Finance, 44, 421-449. 


\section{Table I Year-Wise Summary Statistics for IPOs made in India during 1990-2004}

This table summarizes the data on 2,713 Initial Public Offerings (IPOs) issued in India during 1990-2004, on a yearly basis, for the whole period and for sub-periods (regimes). The data are classified into four groups, based on the nature of the ownership of the firm making the IPO; namely, Private Indian Groups, Stand-Alone Companies, Government Companies and Private Foreign Groups. The initial return is calculated as the proportionate change between the issue price and the first listing price on the stock exchange (the Bombay Stock Exchange). The total amount raised is presented in Indian Rupees. A crore is 10 million Rupees and the current foreign exchange rate (November 2005) is about 45 Indian Rupees to one US \$. The data are also classified into three regimes based on the major structural changes that occurred in the Indian primary market. Regime 1 (Reg 1 ) (1990-95) is the IPO boom period, soon after the liberalization of the Indian economy, when the regulatory restrictions were mild. During Regime 2 (Reg 2) (1996-00) restrictions were introduced regarding pricing and other aspects of the issue. Regime 3 (Reg 3) (2001-04) is the period after the introduction of book-building process for price discovery.

\begin{tabular}{|c|c|c|c|c|c|c|c|c|c|c|c|c|c|c|c|c|c|c|c|}
\hline Year & 1990 & 1991 & 1992 & 1993 & 1994 & 1995 & $\operatorname{Reg} 1$ & 1996 & 1997 & 1998 & 1999 & 2000 & $\operatorname{Reg} 2$ & 2001 & 2002 & 2003 & 2004 & $\operatorname{Reg} 3$ & $\begin{array}{l}\text { Grand } \\
\text { Total }\end{array}$ \\
\hline \multicolumn{20}{|l|}{$\begin{array}{l}\text { Private Indian } \\
\text { Groups }\end{array}$} \\
\hline No. of Issues & 7 & 33 & 74 & 100 & 129 & 72 & 415 & 32 & 7 & - & 10 & 12 & 61 & 1 & 4 & 1 & 2 & 8 & 484 \\
\hline $\begin{array}{l}\text { Total Amount Raised } \\
\text { (In Rs. Crores) }\end{array}$ & 147 & 497.7 & 1045.7 & 1334.3 & 2354.7 & 4389.1 & 9768.0 & 1290.9 & 1086 & - & 1111.9 & 1591.6 & 5080.4 & 49.89 & 1561.5 & 95 & 402.1 & 2108.5 & 16957 \\
\hline $\begin{array}{l}\text { Average Issue Size } \\
\text { (In. Rs. Crores) }\end{array}$ & 8.61 & 15.08 & 14.12 & 13.34 & 17.03 & 30.12 & 17.36 & 14.51 & 35.28 & - & 111.19 & 135.13 & 57.72 & 49.89 & 506.05 & 95 & 201.02 & 253.19 & 25.55 \\
\hline $\begin{array}{l}\text { Average Issue } \\
\text { Premium } \\
\text { (Issue price/Face } \\
\text { value) }\end{array}$ & 1.41 & 1.5 & 1.23 & 4.67 & 2.14 & 2.6 & 3.05 & 2.6 & 1.12 & - & 11.2 & 2.63 & 4.29 & 1 & 5.25 & 5 & 1.1 & 2.83 & 4.63 \\
\hline $\begin{array}{l}\text { Average Initial Return } \\
(\%)\end{array}$ & 85.5 & 299.5 & 219.68 & 141.84 & 93.61 & 34.87 & 145.83 & 18.08 & 38.29 & - & 393.54 & 41.33 & 122.81 & -32.5 & 17.4 & 140 & 80.03 & 51.23 & 140.07 \\
\hline Median Initial Return & 72 & 180 & 90 & 40 & 50 & 20 & 50 & 2.5 & 7.5 & & 393.54 & -3.22 & 10 & -32.5 & 12.9 & 140 & 52.17 & 3.5 & 50 \\
\hline $\begin{array}{l}\text { Average 30-day } \\
\text { Standard Deviation }\end{array}$ & 3.70 & 4.49 & 2.92 & 7. 80 & 5.51 & 5.46 & 5.4 & 2.89 & 3.89 & - & 24.46 & 6.98 & 7.52 & 1.01 & 7.17 & 4.19 & 5.74 & 5.61 & 5.74 \\
\hline \multicolumn{20}{|l|}{$\begin{array}{l}\text { Stand-Alone } \\
\text { Companies }\end{array}$} \\
\hline No. of Issues & 12 & 40 & 129 & 270 & 535 & 738 & 1724 & 329 & 16 & 8 & 15 & 42 & 410 & 10 & - & 2 & 1 & 13 & 2147 \\
\hline $\begin{array}{l}\text { Total Amount Raised } \\
\text { (In Rs. Crores) }\end{array}$ & 130 & 190.3 & 788.94 & 1436.9 & 3382.5 & 4432.1 & 10360 & 1900.2 & 189.9 & 207.3 & 238.48 & 814.23 & 3350.1 & 304.1 & - & 32.6 & 16.95 & 353.66 & 14065 \\
\hline $\begin{array}{l}\text { Average Issue Size } \\
\text { (In. Rs. Crores) }\end{array}$ & 12.9 & 4.64 & 6.11 & 5.32 & 6.32 & 6.01 & 6.01 & 5.7 & 11.87 & 29.62 & 15.89 & 19.38 & 8.20 & 17.12 & - & 16.3 & 16.95 & 16.97 & 6.62 \\
\hline $\begin{array}{l}\text { Average Issue } \\
\text { Premium } \\
\text { (Issue Price/ Face } \\
\text { Value) }\end{array}$ & 1.33 & 1.01 & 1.08 & 1.36 & 1.58 & 1.81 & 1.60 & 1.26 & 1 & 1.24 & 1.26 & 1.58 & 1.28 & 2.37 & - & 1 & 1 & 1.55 & 2.14 \\
\hline $\begin{array}{l}\text { Average Initial Return } \\
(\%)\end{array}$ & 251 & 241.9 & 97.76 & 67.50 & 86.53 & 43.94 & 131.47 & 80.36 & 131.0 & 62.8 & 688.62 & 52.24 & 203.01 & 70.69 & - & 37.5 & 50 & 52.73 & 78.78 \\
\hline Median Initial Return & 250 & 175 & 40 & 30 & 50 & 20 & 33.33 & 10 & 17.25 & 5.26 & 353.75 & 11.66 & 12 & 25 & - & 37.5 & 50 & 37.5 & 30 \\
\hline $\begin{array}{l}\text { Average 30-day } \\
\text { Standard Deviation }\end{array}$ & 8.38 & 5.14 & 2.59 & 2.86 & 3.36 & 3.01 & 3.13 & 1.93 & 3.17 & 3.23 & 13.68 & 2.99 & 2.68 & 2.35 & - & 4.60 & 3.06 & 2.91 & 3.06 \\
\hline
\end{tabular}


Table 1 continued

\begin{tabular}{|c|c|c|c|c|c|c|c|c|c|c|c|c|c|c|c|c|c|c|c|}
\hline Median Initial Return & 225 & 200 & 50 & 33.33 & 50 & 20 & 40 & 10 & 10 & 5.26 & 201.66 & 10 & 11.83 & 20 & 21.59 & 54.58 & 38.49 & 22.85 & 30 \\
\hline $\begin{array}{l}\text { Average } 30 \text { day Standard } \\
\text { Deviation }\end{array}$ & 7.47 & 5.36 & 2.72 & 4.08 & 3.73 & 3.22 & 3.61 & 3.65 & 2.77 & 3.23 & 20.17 & 3.81 & 3.62 & 2.12 & 3.15 & 3.44 & 8.84 & 4.07 & 3.62 \\
\hline \multicolumn{20}{|l|}{ Government Companies } \\
\hline No. of Issues & 1 & - & 1 & 1 & 9 & 2 & 14 & 2 & 5 & - & 1 & 2 & 10 & 1 & 4 & 1 & 3 & 9 & 33 \\
\hline $\begin{array}{l}\text { Total Amount Raised } \\
\text { (In Rs. Crores) }\end{array}$ & - & - & 217.36 & 525 & 765.29 & 2478 & 3985.6 & 1030 & 1287. & - & 125 & 205.1 & 2647.1 & 150 & 937.6 & 240 & 715.1 & 2042.7 & 8675 \\
\hline $\begin{array}{l}\text { Average Issue Size } \\
\text { (In. Rs. Crores) }\end{array}$ & 120 & - & 217.36 & 525 & 85.03 & 1239 & 306.58 & 515 & 257.54 & - & 125 & 102.54 & 264.77 & 150 & 234.42 & 240 & 238.35 & 226.97 & 271.13 \\
\hline $\begin{array}{l}\text { Average Issue Premium } \\
\text { (Issue price/ Face Value) }\end{array}$ & 1 & - & 1.5 & 1 & 3.05 & 2 & 2.5 & 5 & 1.5 & - & 1.5 & 4.75 & 2.66 & 4.27 & 1 & 1 & 5.33 & 2.98 & 3.5 \\
\hline $\begin{array}{l}\text { Average Initial Return } \\
(\%)\end{array}$ & -71 & - & 370 & 21.42 & 55.04 & -20.04 & 106.60 & 146.98 & 10.94 & - & 23 & -4.5 & 44.105 & -5 & 33.58 & 49.1 & 52.18 & 32.46 & 53.62 \\
\hline Median Initial Return & -71 & - & 370 & 21.42 & 5 & -20.04 & 0.57 & 146.98 & 8.88 & - & 23 & -4.5 & 8.19 & -5 & 2.5 & 49.1 & 52.17 & 22.85 & 11.66 \\
\hline $\begin{array}{l}\text { Average 30-day Standard } \\
\text { Deviation }\end{array}$ & 55.3 & - & 1.38 & 4.07 & 4.38 & 2.57 & 7.5 & 2.78 & 6.47 & - & 0.63 & 0.33 & 4.92 & 0.25 & 1.14 & 0.38 & 2.09 & 1.27 & 1.27 \\
\hline \multicolumn{20}{|l|}{ Private Foreign Groups } \\
\hline No. of Issues & 2 & 9 & 6 & 7 & 8 & 7 & 39 & 3 & - & 1 & 1 & 4 & 9 & - & - & - & 1 & 1 & 49 \\
\hline $\begin{array}{l}\text { Total Amount Raised } \\
\text { (In Rs. Crores) }\end{array}$ & 7.73 & 80.4 & 99.07 & 119.73 & 170.61 & 70.98 & 548.52 & 47.38 & - & 1.75 & 55.13 & 291.04 & 395.3 & - & - & - & 365 & 365 & 1309 \\
\hline $\begin{array}{l}\text { Average Issue Size } \\
\text { (In. Rs. Crores) }\end{array}$ & 3.86 & 8.93 & 16.51 & 17.10 & 21.32 & 21.32 & 14.06 & 10.14 & - & 1.75 & 55.13 & 58.54 & 37.60 & - & - & - & 365 & 365 & 24.99 \\
\hline $\begin{array}{l}\text { Average Issue Premium } \\
\text { (Issue Price/ Face Value) }\end{array}$ & 5.25 & 6.83 & 6.63 & 4.5 & 7.42 & 2.5 & 5.71 & 2.41 & - & 4 & 4.5 & 2.37 & 2.80 & - & - & - & 7 & 7 & 8.76 \\
\hline $\begin{array}{l}\text { Average Initial Return } \\
(\%)\end{array}$ & 275 & 1392. & 157.5 & 261.3 & 92.70 & 24.28 & 367.13 & 44.5 & - & 1899 & 152.2 & 356.54 & 613.06 & - & - & - & 26.98 & 26.98 & 351.01 \\
\hline Median Initial Return & 275 & 700 & 115 & 137.5 & 75 & 30 & 100 & 50 & - & 1899 & 152.22 & 21.77 & 26.98 & - & - & - & 26.98 & 26.98 & 75 \\
\hline $\begin{array}{l}\text { Average } 30 \text { day Standard } \\
\text { Deviation }\end{array}$ & 2.22 & 9.99 & 2.88 & 3.09 & 2.90 & 3.01 & 4.56 & 1.17 & - & 8.73 & 94.4 & 5.49 & 14.27 & - & - & - & 5.49 & 36.78 & 7.08 \\
\hline \multicolumn{20}{|l|}{$\begin{array}{l}\text { Descriptive Statistics of } \\
\text { the Total Sample } \\
\end{array}$} \\
\hline No. of Issues & 22 & 82 & 210 & 378 & 681 & 819 & 2192 & 366 & 28 & 9 & 27 & 60 & 490 & 12 & 8 & 4 & 7 & 31 & 2713 \\
\hline $\begin{array}{l}\text { Total Amount Raised } \\
\text { (In Rs. Crores) }\end{array}$ & $\begin{array}{l}10.5 \\
6\end{array}$ & 9.25 & 10.27 & 9.03 & 9.68 & 11.14 & 10.15 & 17.16 & 58.64 & 29.62 & 56.68 & 46.44 & 19.64 & 30.41 & 324.96 & 91.90 & 225.92 & 147.67 & 13.22 \\
\hline $\begin{array}{l}\text { Average Issue Size } \\
\text { (In. Rs. Crores) }\end{array}$ & $\begin{array}{l}27.6 \\
9\end{array}$ & 60.54 & 70.13 & 73.50 & 54.36 & 90.01 & 73.28 & 469.65 & 2726.5 & 2177.2 & 1294.5 & 362.10 & 480.28 & 2951.7 & $\begin{array}{l}36665 . \\
6\end{array}$ & 8845.7 & $\begin{array}{l}11122 . \\
5\end{array}$ & $\begin{array}{l}14738 . \\
5\end{array}$ & 309.47 \\
\hline $\begin{array}{l}\text { Average Issue Premium } \\
\text { (Issue price/ Face Value) }\end{array}$ & 4.86 & 1.03 & 1.43 & 1.82 & 2.23 & 1.90 & 1.95 & 2.86 & 1.56 & 3.37 & 13.16 & 10.12 & 3.17 & 4.96 & 19.85 & 9.8 & 30.9 & 14.60 & 2.29 \\
\hline $\begin{array}{l}\text { Average Initial Return } \\
(\%)\end{array}$ & $\begin{array}{l}249 . \\
47\end{array}$ & 389.49 & 145.23 & 90.63 & 87.67 & 42.87 & 90.88 & 105.56 & 103.94 & 62.86 & 534.82 & 121.81 & 111.02 & 70.69 & 26.68 & 66.06 & 38.32 & 49.21 & 95.36 \\
\hline
\end{tabular}


Table II Comprehensive Descriptive Statistics for IPOs issued in India during 1990-2004

This table summarizes the data on 2,713 Initial Public Offerings (IPOs) issued in India during 1990-2004, in terms of various descriptive statistics. The data are classified into four groups, based on the nature of the ownership of the firm making the IPO; namely, Private Indian Groups, Stand-alone Companies, Government Companies and Private Foreign Groups. The initial return is calculated as the proportionate change between the issue price and the first listing price on the stock exchange (the Bombay Stock Exchange). The average asset size and the issue size are presented in crores of Indian Rupees. A crore is 10 million Rupees and the current foreign exchange rate (November 2005) is about 45 Indian Rupees to one US \$. The average 30-day standard deviation is calculated by using the stock returns from day 1 to day 30 after the stock is listed on the stock exchange. Each variable's standard deviation is reported in parentheses.

\begin{tabular}{|c|c|c|c|c|}
\hline Variables of Interest & $\begin{array}{c}\text { Private Indian } \\
\text { Groups }\end{array}$ & $\begin{array}{c}\text { Stand-Alone } \\
\text { Companies }\end{array}$ & Government Companies & $\begin{array}{c}\text { Private Foreign } \\
\text { Groups }\end{array}$ \\
\hline Average Initial Return (\%) & $\begin{array}{c}140.07 \\
(349.46)\end{array}$ & $\begin{array}{c}78.78 \\
(285.44)\end{array}$ & $\begin{array}{c}53.62 \\
(100.06)\end{array}$ & $\begin{array}{c}351.01 \\
(855.99)\end{array}$ \\
\hline Average 30 day Standard Deviation (\%) & $\begin{array}{c}5.74 \\
(11.29)\end{array}$ & $\begin{array}{l}3.06 \\
(4.77)\end{array}$ & $\begin{array}{c}1.27 \\
(10.14)\end{array}$ & $\begin{array}{c}7.08 \\
(14.14)\end{array}$ \\
\hline Average Asset Size at the time of IPO (In Rs. Crores) & $\begin{array}{c}102.83 \\
(384.82)\end{array}$ & $\begin{array}{c}360.44 \\
(251.05)\end{array}$ & $\begin{array}{c}17194.92 \\
(20963.42)\end{array}$ & $\begin{array}{c}64.21 \\
(133.94)\end{array}$ \\
\hline Average Issue Size (In Rs. Crores) & $\begin{array}{c}25.5 \\
(85.33)\end{array}$ & $\begin{array}{c}6.62 \\
(11.97)\end{array}$ & $\begin{array}{c}271.13 \\
(427.08)\end{array}$ & $\begin{array}{c}24.99 \\
(57.03)\end{array}$ \\
\hline Average Issue Premium (Issue Price/Face Value) & $\begin{array}{c}4.63 \\
(11.08)\end{array}$ & $\begin{array}{c}2.14 \\
(2.70)\end{array}$ & $\begin{array}{c}3.5 \\
(2.95)\end{array}$ & $\begin{array}{c}8.76 \\
(24.09)\end{array}$ \\
\hline Average Promoters' Subscription (\%) & $\begin{array}{c}17.34 \\
(22.92)\end{array}$ & $\begin{array}{c}12.54 \\
(16.64)\end{array}$ & $\begin{array}{c}3.76 \\
(18.90)\end{array}$ & $\begin{array}{c}14.82 \\
(26.91)\end{array}$ \\
\hline Average Public Subscription (\%) & $\begin{array}{l}68.63 \\
(27.01)\end{array}$ & $\begin{array}{c}64.38 \\
(20.97)\end{array}$ & $\begin{array}{c}69.50 \\
(27.22)\end{array}$ & $\begin{array}{l}75.28 \\
(28.90)\end{array}$ \\
\hline $\begin{array}{l}\text { Average Institutional and Others Subscription (\%) } \\
\text { Raw Buy and Hold Return ( } 36 \text { Months) (\%) }\end{array}$ & $\begin{array}{c}14.03 \\
(19.10) \\
57\end{array}$ & $\begin{array}{c}23.08 \\
(16.25) \\
85\end{array}$ & $\begin{array}{c}26.74 \\
(18.32) \\
88\end{array}$ & $\begin{array}{c}9.90 \\
(17.21) \\
56\end{array}$ \\
\hline Average oversubscription (times) & $\begin{array}{c}14.23 \\
(20.53)\end{array}$ & $\begin{array}{c}9.06 \\
(55.43)\end{array}$ & $\begin{array}{c}6.25 \\
(7.23)\end{array}$ & $\begin{array}{c}14.16 \\
(21.91)\end{array}$ \\
\hline Percentage of Companies in Z-group of BSE (as of 31.12. 2004) & 13 & 86 & 0.1 & 0.9 \\
\hline Number of Observations & 484 & 2147 & 33 & 49 \\
\hline
\end{tabular}


Table III One-Way ANOVA Multiple Means Comparison Test for IPOs of Private Indian Groups, Stand-Alone Companies, Government Companies, and Private Foreign Groups during 1990-2004

This table is based on data for 2,713 Initial Public Offerings (IPOs) issued in India during 1990-2004. The data are classified into four groups, based on the nature of the ownership of the firm making the IPO; namely, Private Indian Groups, Stand-alone Companies, Government Companies and Private Foreign Groups. The initial return is calculated as the proportionate change between the issue price and the first listing price on the stock exchange (Bombay Stock Exchange). The asset size and issue size are presented in crores of Indian Rupees. A crore is 10 million Rupees and the current foreign exchange rate (November 2005) is about 45 Indian Rupees to one US \$. The test statistic presented below relates to the differences between the means in different groups based on the Tukey multiple comparison test. This test allows a comparison of the means simultaneously for multiple samples. For instance, in the case of the initial return variable, the Private Indian Group sample mean is first compared with that of the other three groups. The StandAlone Companies sample is also compared in the same manner, but leaving out the Private Indian Group sample, which was compared in the first set. * and ** indicates significance at the $1 \%$ and $5 \%$ level respectively. The $p$-values are in parentheses.

\begin{tabular}{|c|c|c|c|c|c|c|c|c|c|}
\hline & $\begin{array}{l}\text { Private } \\
\text { Indian } \\
\text { Groups }\end{array}$ & $\begin{array}{c}\text { Stand-alone } \\
\text { Companies }\end{array}$ & $\begin{array}{c}\text { Government } \\
\text { Companies }\end{array}$ & $\begin{array}{c}\text { Private } \\
\text { Foreign } \\
\text { Groups }\end{array}$ & & $\begin{array}{l}\text { Private } \\
\text { Indian } \\
\text { Groups }\end{array}$ & $\begin{array}{l}\text { Stand-alone } \\
\text { Companies }\end{array}$ & $\begin{array}{c}\text { Government } \\
\text { Companies }\end{array}$ & $\begin{array}{c}\text { Private } \\
\text { Foreign } \\
\text { Groups }\end{array}$ \\
\hline Initial Return & & & & & Premium & & & & \\
\hline $\begin{array}{l}\text { Private Indian } \\
\text { Groups }\end{array}$ & - & $\begin{array}{l}63.26^{*} \\
(0.001)\end{array}$ & $\begin{array}{l}83.71 \\
(0.427)\end{array}$ & $\begin{array}{c}-214.26^{*} \\
(0.000)\end{array}$ & & - & $\begin{array}{l}2.68^{*} \\
(0.000)\end{array}$ & $\begin{array}{c}1.12 \\
(0.797)\end{array}$ & $\begin{array}{l}-4.12 * \\
(0.001)\end{array}$ \\
\hline $\begin{array}{l}\text { Stand-Alone } \\
\text { Companies }\end{array}$ & & - & $\begin{array}{c}20.44 \\
(0.981)\end{array}$ & $\begin{array}{c}-277.53^{*} \\
(0.000)\end{array}$ & & & - & $\begin{array}{l}-1.55 \\
(0.564)\end{array}$ & $\begin{array}{l}-6.18^{*} \\
(0.000)\end{array}$ \\
\hline $\begin{array}{l}\text { Government } \\
\text { Companies }\end{array}$ & & & $\begin{array}{c}(0.301) \\
-\end{array}$ & $\begin{array}{c}-297.98^{*} \\
(0.000)\end{array}$ & & & & $\begin{array}{c}(0.504) \\
-\end{array}$ & $-5.25^{*}$ \\
\hline $\begin{array}{c}\text { Private Foreign } \\
\text { Groups }\end{array}$ & & & & - & & & & & - \\
\hline Asset Size & & & & & $\begin{array}{c}\text { Promoters' } \\
\text { Subscription }\end{array}$ & & & & \\
\hline $\begin{array}{l}\text { Private Indian } \\
\text { Groups }\end{array}$ & - & $\begin{array}{c}68.38 \\
(0.966)\end{array}$ & $\begin{array}{c}-1792.07^{*} \\
(0.000)\end{array}$ & $\begin{array}{c}38.61 \\
(1.000)\end{array}$ & & - & $\begin{array}{c}0.11 \\
(1.00)\end{array}$ & $\begin{array}{l}16.17 * \\
(0.000)\end{array}$ & $\begin{array}{l}-3.65 \\
(0.654)\end{array}$ \\
\hline $\begin{array}{l}\text { Stand-Alone } \\
\text { Companies }\end{array}$ & & - & $\begin{array}{c}-1716.45^{*} \\
(0.000)\end{array}$ & $\begin{array}{l}-29.76 \\
(1.000)\end{array}$ & & & - & $\begin{array}{l}16.16^{*} \\
(0.000)\end{array}$ & $\begin{array}{l}-3.64 \\
(0.626)\end{array}$ \\
\hline Government & & & - & $1713.69^{*}$ & & & & - & $-19.83^{*}$ \\
\hline $\begin{array}{l}\text { Companies } \\
\text { Private Foreign } \\
\text { Groups }\end{array}$ & & & & $\begin{array}{c}(0.000) \\
-\end{array}$ & & & & & $(0.000)$ \\
\hline Issue Size & & & & & $\begin{array}{c}\text { Public } \\
\text { Subscription }\end{array}$ & & & & \\
\hline $\begin{array}{l}\text { Private Indian } \\
\text { Groups }\end{array}$ & - & $\begin{array}{l}20.95^{*} \\
(0.000)\end{array}$ & $\begin{array}{c}-252.13^{*} \\
(0.000)\end{array}$ & $\begin{array}{c}0.113 \\
(1.000)\end{array}$ & & - & $\begin{array}{c}3.15 \\
(1.00)\end{array}$ & $\begin{array}{l}14.72 * \\
(0.003)\end{array}$ & $\begin{array}{c}0.62 \\
(0.998)\end{array}$ \\
\hline Stand-Alone & & - & -1.55 & $-6.81 *$ & & & - & $-17.87^{*}$ & -2.53 \\
\hline
\end{tabular}




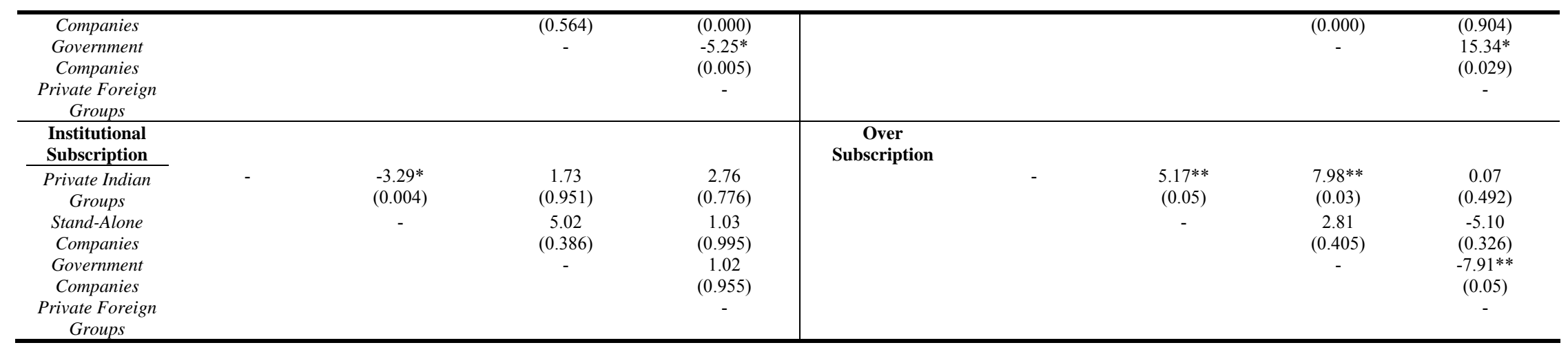




\section{Table IV Regression Results with Initial Return as the Dependent Variable}

This table is based on data on 2,713 Initial Public Offerings (IPOs) issued in India during 1990-2004. The table presents multiple regression results based on the following equations. (Note: For brevity, only one regression equation is reported. The other equations are nested in Regression 7 below, but with fewer variables on the right hand side). Regression 7: $\operatorname{Ln}($ Initial return+1) $=\mathrm{c}+\mathrm{a} 1 \operatorname{Ln}($ Asset Size $)+\mathrm{a} 2 \mathrm{Ln}($ Issue Size $)+$ a3 Private Indian Groups dummy + a4 Stand-Alone Companies dummy + a5 Government Companies dummy + a6 Private Foreign Group dummy + a7 Banking Companies dummy + a8 Financial services Dummy + a9 Manufacturing Companies dummy + a10 Other Services Companies dummy + a11 Regime1 + a12 Regime $2+$ a13 Regime3 + a14 Promoters' subscription + a15 Public Investors subscription + a16 Institutional Investors subscription + a17 Other investors contribution + a18 Extent of Subscription + a19 Underwriter Quality + e

The regressions are aimed at testing the relationship between underpricing and variables of interest; namely: asset size, issue size, Private Indian Group dummy, Stand-Alone Companies dummy, Government Companies dummy, Private Foreign Group dummy, Banking Companies dummy, Financial Services (ex-banking) Companies dummy, Manufacturing Companies dummy, Other Sectors dummy. Promoter's Subscription represents the percentage invested by the promoters for the IPO; Public Investors Subscription represents the percentage subscribed by the public for the IPO; Institutional Investors' Subscription represents the percentage invested by the institutional investors, while Other Investor's Subscription (omitted here as an independent variable) represents the rest of the participation in the IPO. Extent of subscription reports how many times an issue is over or under subscribed. Value 1 indicates no over or under subscription. Underwriter quality is a dummy variable that takes value 1 if the underwriter is one of the top 5 (top 10 in Regression 6) underwriters in terms of the value underwritten. Apart from these variables, the table also reports the coefficients for the regime dummies. Regime 1 is a dummy variable for regime 1 (1990-1995); Regime 2 is a dummy variable for regime 2 (1996-2000); Regime 3 is a dummy variable for regime 3 (2001-2004). The extent of subscription measures the number of time an IPO is over subscribed. Regression 8 presents the results from the second stage of the two-stage least squares regression using firm size as the instrument variable. $*$.

\begin{tabular}{|c|c|c|c|c|c|c|c|c|}
\hline $\begin{array}{l}\text { Independent } \\
\text { Variables }\end{array}$ & Regression 1 & Regression 2 & Regression 3 & Regression 4 & Regression 5 & Regression 6 & Regression 7 & Regression 8 \\
\hline $\mathrm{C}$ & $\begin{array}{l}3.88 \\
(36.66)^{* * *}\end{array}$ & $\begin{array}{l}3.94 \\
(33.51)^{* * *}\end{array}$ & $\begin{array}{l}4.27 \\
(8.41)^{* * *}\end{array}$ & $\begin{array}{l}5.20 \\
(5.86)^{* * *}\end{array}$ & $\begin{array}{l}0.978 \\
(3.54)^{* * * *}\end{array}$ & $\begin{array}{l}1.26 \\
(4.22)^{* * *}\end{array}$ & $\begin{array}{l}1.26 \\
(4.21)^{* * * *}\end{array}$ & $\begin{array}{l}5.68 \\
(3.42)^{* * *}\end{array}$ \\
\hline $\begin{array}{l}\text { Asset Size (at the time } \\
\text { of IPO) }\end{array}$ & $\begin{array}{l}0.519 \\
(1.22)\end{array}$ & $\begin{array}{l}0.381 \\
(0.84)\end{array}$ & $0.023(0.52)$ & $\begin{array}{l}0.042 \\
(0.90)\end{array}$ & $\begin{array}{l}-0.006 \\
(-0.34)\end{array}$ & $\begin{array}{l}-0.007 \\
(-0.47)\end{array}$ & $\begin{array}{l}-0.008 \\
(-0.53)\end{array}$ & - \\
\hline Issue Size & $\begin{array}{l}-0.293 \\
(-4.37)^{* * *}\end{array}$ & $\begin{array}{l}-0.300 \\
(-4.45)^{* * *}\end{array}$ & $\begin{array}{l}-0.259 \\
(-3.81)^{* * *}\end{array}$ & $\begin{array}{l}-0.272 \\
(-3.84)^{* * *}\end{array}$ & $\begin{array}{l}-0.068 \\
(-2.63)^{* *}\end{array}$ & $\begin{array}{l}-0.082 \\
(-3.37)^{* * *}\end{array}$ & $\begin{array}{l}-0.077 \\
(-3.20)^{* * *}\end{array}$ & $\begin{array}{l}-0.05 \\
(-0.36)\end{array}$ \\
\hline $\begin{array}{l}\text { Private Indian Group } \\
\text { dummy }\end{array}$ & $\begin{array}{l}0.763 \\
(7.30)^{* * *}\end{array}$ & $\begin{array}{l}0.778 \\
(7.35)^{* * *}\end{array}$ & $\begin{array}{l}0.714 \\
(6.72)^{* * *}\end{array}$ & $\begin{array}{l}0.698 \\
(6.57)^{* * *}\end{array}$ & $\begin{array}{l}0.246 \\
(4.97)^{* * *}\end{array}$ & $\begin{array}{l}0.233 \\
(4.75)^{* * *}\end{array}$ & $\begin{array}{l}0.228 \\
(4.58)^{* * *}\end{array}$ & $\begin{array}{l}0.609 \\
(2.21)^{* *}\end{array}$ \\
\hline $\begin{array}{l}\text { Stand-Alone } \\
\text { Companies dummy }\end{array}$ & - & - & - & - & - & - & - & - \\
\hline $\begin{array}{l}\text { Government } \\
\text { Companies dummy }\end{array}$ & $\begin{array}{l}0.606 \\
(1.51)\end{array}$ & $\begin{array}{l}0.460 \\
(0.94)\end{array}$ & $\begin{array}{l}0.384 \\
(0.78)\end{array}$ & $\begin{array}{l}0.356 \\
(0.72)\end{array}$ & $\begin{array}{l}0.059 \\
(0.32)\end{array}$ & $\begin{array}{l}0.619 \\
(0.34)\end{array}$ & $\begin{array}{l}0.049 \\
(0.27)\end{array}$ & $\begin{array}{l}-0.08 \\
(-0.07)\end{array}$ \\
\hline $\begin{array}{l}\text { Private Foreign } \\
\text { Group dummy }\end{array}$ & $\begin{array}{l}1.319 \\
(4.76)^{* * *}\end{array}$ & $\begin{array}{l}1.362 \\
(4.77)^{* * *}\end{array}$ & $\begin{array}{l}1.36 \\
(4.93)^{* * *}\end{array}$ & $\begin{array}{l}1.31 \\
(4.79)^{* * *}\end{array}$ & $\begin{array}{l}0.382 \\
(2.81)^{* *}\end{array}$ & $\begin{array}{l}0.382 \\
(2.84)^{* *}\end{array}$ & $\begin{array}{l}0.371 \\
(2.75)^{* *}\end{array}$ & $\begin{array}{l}0.829 \\
(1.77)^{*}\end{array}$ \\
\hline $\begin{array}{l}\text { Banking Companies } \\
\text { dummy }\end{array}$ & & $\begin{array}{l}0.340 \\
(0.67)\end{array}$ & $\begin{array}{l}0.417 \\
(0.83)\end{array}$ & $\begin{array}{l}0.434 \\
(0.87)\end{array}$ & $\begin{array}{l}0.265 \\
(1.37)\end{array}$ & $\begin{array}{l}0.263 \\
(1.43)\end{array}$ & $\begin{array}{l}0.262 \\
(1.42)\end{array}$ & $\begin{array}{l}0.19 \\
(0.11)\end{array}$ \\
\hline $\begin{array}{l}\text { Financial Services } \\
\text { Companies dummy }\end{array}$ & & $\begin{array}{l}-0.125 \\
(-1.14)\end{array}$ & $\begin{array}{l}-0.117 \\
(-1.08)\end{array}$ & $\begin{array}{l}-0.134 \\
(-1.23)\end{array}$ & $\begin{array}{l}-0.07 \\
(-1.20)\end{array}$ & $\begin{array}{l}-0.062 \\
(-1.33)\end{array}$ & $\begin{array}{l}-0.065 \\
(-1.40)\end{array}$ & $\begin{array}{l}-0.13 \\
(-0.48)\end{array}$ \\
\hline
\end{tabular}




\begin{tabular}{|c|c|c|c|c|c|c|c|c|}
\hline $\begin{array}{l}\text { Manufacturing } \\
\text { Companies dummy }\end{array}$ & & - & - & - & - & - & - & - \\
\hline $\begin{array}{l}\text { Other Services } \\
\text { Companies dummy }\end{array}$ & & $\begin{array}{l}0.001 \\
(0.02)\end{array}$ & $\begin{array}{l}0.038 \\
(0.33)\end{array}$ & $\begin{array}{l}0.054 \\
(0.46)\end{array}$ & $\begin{array}{l}0.001 \\
(0.02)\end{array}$ & $\begin{array}{l}0.24 \\
(0.52)\end{array}$ & $\begin{array}{l}0.02 \\
(0.51)\end{array}$ & $\begin{array}{l}0.122 \\
(042)\end{array}$ \\
\hline Regime 1 & & & $\begin{array}{l}-0.289 \\
(-0.61)\end{array}$ & $\begin{array}{l}-0.335 \\
(-0.71)\end{array}$ & $\begin{array}{l}-0.105 \\
(-0.67)\end{array}$ & $\begin{array}{l}-0.134 \\
(-0.89)\end{array}$ & $\begin{array}{l}-0.133 \\
(-0.88)\end{array}$ & $\begin{array}{l}-2.405 \\
(-2.71)^{* *}\end{array}$ \\
\hline Regime 2 & & & $\begin{array}{l}-0.808 \\
(-1.99)^{* *}\end{array}$ & $\begin{array}{l}-0.841 \\
(-1.99)^{* *}\end{array}$ & $\begin{array}{l}-0.273 \\
(-1.75)^{*}\end{array}$ & $\begin{array}{l}-0.278 \\
(-1.83)^{*}\end{array}$ & $\begin{array}{l}-0.272 \\
(-1.79)^{*}\end{array}$ & $\begin{array}{l}-2.11 \\
(-2.42)^{* *}\end{array}$ \\
\hline Regime 3 & & & - & - & - & - & - & - \\
\hline $\begin{array}{l}\text { Promoters' } \\
\text { contribution }\end{array}$ & & & & $\begin{array}{l}-0.002 \\
(-0.29)\end{array}$ & $\begin{array}{l}-0.494 \\
(-0.175)^{*}\end{array}$ & $\begin{array}{l}-0.449 \\
(-0.62)\end{array}$ & $\begin{array}{l}-0.454 \\
(-1.64)\end{array}$ & $\begin{array}{l}-2.32 \\
(-1.50)\end{array}$ \\
\hline $\begin{array}{l}\text { Public investors } \\
\text { contribution }\end{array}$ & & & & $\begin{array}{l}-0.011 \\
(-1.39)\end{array}$ & $\begin{array}{l}-0.73 \\
(-2.71)^{* *}\end{array}$ & $\begin{array}{l}-0.725 \\
(-2.72)^{* *}\end{array}$ & $\begin{array}{l}-0.74 \\
(-2.67)^{* *}\end{array}$ & $\begin{array}{l}-2.97 \\
(-2.01)^{* *}\end{array}$ \\
\hline $\begin{array}{l}\text { Institutional investors } \\
\text { contribution }\end{array}$ & & & & $\begin{array}{l}-0.011 \\
(-1 . .96)^{* *}\end{array}$ & $\begin{array}{l}-0.801 \\
(-2.80)^{* *}\end{array}$ & $\begin{array}{l}-0.778 \\
(-2.80)^{* *}\end{array}$ & $\begin{array}{l}-0.78 \\
(-2.84)^{* *}\end{array}$ & $\begin{array}{l}-2.87 \\
(-1.85)^{* *}\end{array}$ \\
\hline $\begin{array}{l}\text { Other investors' } \\
\text { contribution }\end{array}$ & - & - & - & - & - & - & - & - \\
\hline Extent of Subscription & & & & & $\begin{array}{l}0.01 \\
(5.03) * * *\end{array}$ & $\begin{array}{l}0.01 \\
(5.20) * * *\end{array}$ & $\begin{array}{l}0.01 \\
(5.24) * * *\end{array}$ & $\begin{array}{l}0.04 \\
(1.87)^{* *}\end{array}$ \\
\hline $\begin{array}{l}\text { Underwriter Quality } \\
\text { (top ten/ top five) }\end{array}$ & & & & & & $\begin{array}{l}0.065 \\
(1.79)^{*}\end{array}$ & $\begin{array}{l}0.06 \\
(1.57)\end{array}$ & $\begin{array}{l}-0.11 \\
(-0.05)\end{array}$ \\
\hline $\mathbf{N}$ & 1914 & 1913 & 1913 & 1905 & 1905 & 1905 & 1905 & 1245 \\
\hline Adj. $\mathbf{R}^{2}$ & 0.047 & 0.049 & 0.06 & 0.065 & 0.075 & 0.073 & 0.072 & 0.827 \\
\hline
\end{tabular}




\section{Table V Results of Propensity Score Matching}

This table reports the $t$-values based on mean difference tests for various firm characteristics of Indian group-affiliated firms and stand-alone firms. The variables are first sorted into quintiles (Q1 to Q5 in the table) based on their propensity scores. The propensity scores are calculated using a logistic regression with the probability of underpricing as the dependent variable and all the variables reported in Table 4 as independent variables. The dependent variable takes value 1 ( 0 ) for underpricing (no underpricing). Underpricing is defined based on a cut-off of $0 \%$ - firms with underpricing above (below) $0 \%$ are defined to be underpriced (not underpriced). $N$ reports number of stand-alone firm observations (Indian group observations). The reported values are t-values using non-parametric Wilcoxon signed rank test. $* * *$ and $* * *$ indicate significance at the $10 \%, 5 \%$ and $1 \%$ level, respectively.

\begin{tabular}{|c|c|c|c|c|c|}
\hline Variable & Q1 & $Q 2$ & Q3 & $Q 4$ & Q5 \\
\hline Asset Size & $-7.81 * * *$ & $-8.39 * * *$ & $-7.29 * * *$ & $-9.91 * * *$ & $-9.20 * * *$ \\
\hline Issue Size & $-8.06 * * *$ & $-9.82 * * *$ & $-8.89 * * *$ & $-9.82 * * *$ & $-7.39 * * *$ \\
\hline $\begin{array}{l}\text { Share } \\
\text { Premium }\end{array}$ & $-6.19 * * *$ & $-4.52 * * *$ & $-6.65 * * *$ & $-9.63 * * *$ & $-1.94 * *$ \\
\hline $\begin{array}{l}\text { Promoter's } \\
\text { Subscription }\end{array}$ & -1.13 & -1.60 & $-1.88 *$ & $-3.15 * * *$ & $-4.48 * * *$ \\
\hline $\begin{array}{l}\text { Public } \\
\text { Subscription }\end{array}$ & $-5.38 * * *$ & -0.88 & $-3.02 * * *$ & $-4.35 * * *$ & $-4.07 * * *$ \\
\hline $\begin{array}{l}\text { Institutional } \\
\text { Subscription }\end{array}$ & -0.25 & $-3.31 * * *$ & -0.859 & $-2.25 * *$ & $-4.11 * * *$ \\
\hline $\begin{array}{l}\text { Over } \\
\text { Subscription }\end{array}$ & $-4.17 * * *$ & $-2.55 * *$ & $-2.71 * *$ & $-2.89 * *$ & $-2.36 * *$ \\
\hline $\mathbf{N}$ & $315(47)$ & $315(47)$ & $339(44)$ & $217(44)$ & $187(170)$ \\
\hline
\end{tabular}




\section{Table VI Ordered Probit Model Results}

This table is based on data on 2,713 Initial Public Offerings (IPOs) issued in India during 1990-2004. The table reports IPO post-performance results. We use an ordered probit model to measure the likelihood of success (or failure) for a given IPO after listing on the stock exchange. The proxy for success (or failure) is the current (as of Dec. 2004) listing category on the Bombay Stock Exchange (BSE). The BSE classifies all listed firms into different quality bands. There are four main quality-based bands on the BSE; namely, A, B1, B2, and Z. The A band represents the best quality stocks in terms of size, liquidity and financial performance and the rest follow in hierarchical sequence, with the $Z$ band representing firms that have violated BSE listing norms or have been declared bankrupt. In the ordered probit model, firms take the values 1 through 4 , corresponding to current listing bands of A, B1, B2 and Z, respectively. We also use all the control variables that are used in Table 4. The ordered probit model (Model 4) is represented as follows: Prob(Failure) $=\mathrm{c}+\mathrm{b} 1 \mathrm{Ln}(\mathrm{Size}$ of firm at the time of IPO) $+\mathrm{b} 2$ (Private Indian Group dummy) + b3 (Stand-Alone Companies dummy) + b4 (Government Companies dummy) + b5 (Private Foreign Group dummy) + b6 (Banking Companies dummy) + b7 (Financial Services Companies dummy ) + b8 (Manufacturing Companies dummy) + b9 (Other Services dummy) + b10 (Regime 1) + b11 (Regime 2) + b12 (Regime 3 dummy) + b13 (Promoters' Contribution) + b14 (Public Investors' Contribution) + b15 (Institutional Investors' Contribution $)+b 16$ (Other Investors' Contribution) + b17 $\operatorname{Ln}(\%$ of initial return +1$)+$ e. Note that models 1,2 and 3 are variations of model 4 , with or without sector dummies, regime dummies and subscription details, respectively. Model 5 includes all variables that are presented in the table. $*, * *, * * *$ represent significant levels at the $10 \%, 5 \%$ and $1 \%$ levels respectively. The $z$-values are in parentheses.

\begin{tabular}{l|llll}
\hline & Model 1 & Model 2 & Model 3 & Model 4 \\
\hline C & - & - & - & - \\
Asset Size (at the time of IPO) & -0.260 & -0.235 & -0.221 & -.207 \\
Private Indian Group dummy & $(-10.14)^{* * *}$ & $(-8.39)^{* * *}$ & $(-7.71)^{* * *}$ & $(-7.09)^{* * *}$ \\
Stand-Alone Companies dummy & -3.48 & -0.380 & -0.422 & -0.419 \\
Government Companies dummy & $(-4.53)^{* * *}$ & $(-4.87)^{* * *}$ & $(-5.37)^{* * *}$ & $(-5.28)^{* * *}$ \\
Private Foreign Group dummy & - & - & - & - \\
Banking Companies dummy & -0.983 & -0.53 & -0.358 & -0.35 \\
Financial Services Companies dummy & $(-3.27)^{* * *}$ & $(-1.51)$ & $(-0.99)$ & $(-0.97)$ \\
Manufacturing Companies dummy & -0.809 & -0.840 & -0.789 & -0.785 \\
& $(-3.99)^{* * *}$ & $(-4.14)^{* * *}$ & $(-3.87)^{* * *}$ & $(-3.83)^{* * *}$ \\
Other Services Companies dummy & - & -0.917 & -0.899 & -0.966 \\
Regime 1 & - & $(-2.47)^{* *}$ & $(-2.42)^{* *}$ & $(-2.57)^{* *}$ \\
& - & -0.189 & -0.017 & 0.01 \\
& - & $-0.23)$ & $(-0.21)$ & $(0.13)$ \\
\end{tabular}




\begin{tabular}{l|llll}
\hline Regime 2 & - & - & 0.414 & 0.305 \\
Regime 3 & - & - & $(1.16)$ & $(0.85)$ \\
Promoters' contribution & - & - & - \\
Public investors' contribution & - & - & - & 0.004 \\
Institutional investors' contribution & - & - & - & $(1.33)$ \\
Other investors' contribution & - & - & - & $(1.33)$ \\
Extent of underpricing & - & - & -008 \\
N & -0.060 & -0.060 & $-0.22)$ \\
Log Likelihood & $(-3.32)^{* *}$ & $-(-3.28)^{* *}$ & $(-3.83)^{* * *}$ & -0.071 \\
Pseudo R-Square & 1884 & 1884 & 1884 & $(-3.77)^{* * *}$ \\
& -1445.51 & -1441.94 & -1429.85 & -1441.93 \\
\hline
\end{tabular}




\section{Table VII Additional Test for the Co-insurance Hypothesis}

This table reports the results of additional tests of the co-insurance hypothesis. The results are arranged in two panels: Panel A reports the mean difference test results between profit- and loss-making firms, for each year from 2000 to 2005 and for the aggregate values for all the years in the last column. The mean values are presented in crores A crore is 10 million and the current foreign exchange rate (November 2005) is about 45 Indian Rupees to one US \$. The t-values are reported in the last row of Panel A. Panel B reports regression results to understand the relationship between the extent of loans and borrowing and firm operative income. The dependent variable in the first [second] column Loan To Group Firms (LTG) [Borrowing From Group Firms (BFG)]. The independent variables are Profit Before Depreciation, Interest and Taxes (PBDIT), Age of the firms (Ln(Age), Total Assets (Ln(TA), and Solvency Ratio (SR) respectively. The t-values are reported in parentheses. The mean values are presented in crores A crore is 10 million and the current foreign exchange rate (November 2005) is about 45 Indian Rupees to one US \$. The t-values are reported in the last row of Panel C. The *,**,*** represent significance at the $10 \%, 5 \%$ and $1 \%$ levels, respectively.

\begin{tabular}{|c|c|c|c|c|c|c|c|c|c|c|c|c|c|c|}
\hline \multicolumn{15}{|c|}{ PANEL A: Mean Difference Analysis for Testing Co-insurance Hypothesis } \\
\hline & LTG & BFG & LTG & BFG & LTG & BFG & LTG & BFG & LTG & BFG & LTG & BFG & LTG & BFG \\
\hline LOSS & 4.24 & 0.47 & 2.65 & 0.32 & 3.06 & 1.46 & 4.37 & 1.61 & 1.88 & 2.55 & 1.74 & 4.19 & 3.80 & 1.15 \\
\hline PROFIT & 9.29 & 0.38 & 9.70 & 0.69 & 13.04 & 0.67 & 18.76 & 0.51 & 20.43 & 0.55 & 36.66 & 0.25 & 15.80 & 0.61 \\
\hline t-value & -1.27 & 0.36 & $-2.04 *$ & -1.39 & $-1.99 *$ & 0.60 & $1.99 *$ & 0.82 & $-2.07 *$ & 1.18 & -1.51 & 1.03 & $-4.16^{* * *}$ & 1.19 \\
\hline
\end{tabular}

\begin{tabular}{|c|c|c|}
\hline PANEL I & ession Analy & is for Testi \\
\hline & LTG & BFG \\
\hline Intercept & $\begin{array}{l}8.80 \\
(17.12)^{* * *}\end{array}$ & $\begin{array}{l}-0.609 \\
-1.160\end{array}$ \\
\hline PBDIT & 0.504 & -0.005 \\
\hline & $(14.21)^{* * *}$ & $(-0.15)$ \\
\hline $\operatorname{Ln}(\mathrm{TA})$ & -20.27 & 0.238 \\
\hline & $(-21.65)^{* * *}$ & $(3.18)^{* * *}$ \\
\hline Ln(Age) & $\begin{array}{l}-0.14 \\
(-2.22) * *\end{array}$ & $\begin{array}{l}0.002 \\
(0.52)\end{array}$ \\
\hline SR & $\begin{array}{l}(-2.22) \\
-1.58\end{array}$ & 0.003 \\
\hline & $(-3.34)^{* * *}$ & $(0.13)$ \\
\hline Adj. $R^{2}$ & 0.83 & 0.09 \\
\hline $\mathbf{N}$ & 4271 & 4271 \\
\hline
\end{tabular}




\section{Table VIII IPO Long-Run Performance Results}

This table is based on data on 2,713 Initial Public Offerings (IPOs) issued in India during 1990-2004. The table shows the average cumulative abnormal returns (CAAR) of firms on the BSE 100 index, and the average buy and hold returns (BHAR) of firms on the BSE 100. CAAR and BHAR are calculated and reported for different periods: for 12, 24 and 36 months respectively. The number of observations (N) varies based on the time period used to calculate CAAR and BHAR. CAAR is defined as $1 / \mathrm{nCAR}_{\mathrm{i}}$; where $\mathrm{CAR}_{\mathrm{i}}=\Sigma_{\mathrm{t}=1 \text { to T }}\left(\mathrm{R}_{\mathrm{it}}-\mathrm{R}_{\mathrm{mt}}\right), \mathrm{T}=12$ or 24 or 36 months. BHAR is defined as $1 / \mathrm{n} \mathrm{BHER}_{\mathrm{i}}$; where $\mathrm{BHER}_{\mathrm{i}}=\Pi_{\mathrm{t}=1 \text { to T }}\left(1+\mathrm{R}_{\mathrm{it}}\right)-\Pi_{\mathrm{H}}\left(1+\mathrm{R}_{\mathrm{mt}}\right), \mathrm{T}$

$=12$ or 24 or 36 months, $R_{i t}=$ return of firm $I$ and $R_{m t}$ is the market bench mark return (BSE 100 index return). We also report raw buy and hold returns for the 12,24 and 36 month windows. * indicates values are significant at the 0.01 level. The $t$-values are reported in parentheses.

\begin{tabular}{|c|c|c|c|c|c|c|c|c|c|c|c|c|}
\hline Ownership Type & $\begin{array}{l}\text { Raw } \\
\text { Buy and } \\
\text { Hold } \\
(12 M)\end{array}$ & $\begin{array}{l}\text { CAAR } \\
(12 M)\end{array}$ & $\begin{array}{l}\text { BHAR } \\
(12 M)\end{array}$ & $\begin{array}{l}N \\
(12 M)\end{array}$ & $\begin{array}{l}\text { Raw } \\
\text { Buy and } \\
\text { Hold } \\
(24 M) \\
\end{array}$ & $\begin{array}{l}C A A R \\
(24 M)\end{array}$ & $\begin{array}{l}\text { BHAR } \\
(24 M)\end{array}$ & $\begin{array}{l}N \\
(24 M)\end{array}$ & $\begin{array}{l}\text { Raw } \\
\text { Buy and } \\
\text { Hold } \\
(36 \mathrm{M}) \\
\end{array}$ & $\begin{array}{l}\text { CAAR } \\
(36 \mathrm{M})\end{array}$ & $\begin{array}{l}\text { BHAR } \\
(36 M)\end{array}$ & $\begin{array}{l} \\
(36 M)\end{array}$ \\
\hline $\begin{array}{l}\text { Private Indian } \\
\text { Groups }\end{array}$ & 0.57 & $\begin{array}{l}-0.265 \\
(3.61 *)\end{array}$ & $\begin{array}{l}-0.614 \\
\left(-4.34^{*}\right)\end{array}$ & 92 & 0.51 & $\begin{array}{l}-0.465 \\
(-4.84 *)\end{array}$ & $\begin{array}{l}-0.792 \\
(-6.40 *)\end{array}$ & 83 & 0.57 & $\begin{array}{l}-0.606 \\
\left(-4.76^{*}\right)\end{array}$ & $\begin{array}{l}-0.820 \\
\left(-5.43^{*}\right)\end{array}$ & 79 \\
\hline $\begin{array}{l}\text { Stand-Alone } \\
\text { Companies }\end{array}$ & 0.88 & $\begin{array}{l}-0.065 \\
(-1.46)\end{array}$ & $\begin{array}{l}-0.307 \\
(-1.42)\end{array}$ & 426 & 0.80 & $\begin{array}{l}-0.201 \\
(-3.67 *)\end{array}$ & $\begin{array}{l}-0.792 \\
(-6.40 *)\end{array}$ & 401 & 0.85 & $\begin{array}{l}-0.321 \\
(-4.77 *)\end{array}$ & $\begin{array}{l}-0.820 \\
\left(-5.44^{*}\right)\end{array}$ & 391 \\
\hline $\begin{array}{l}\text { Private Foreign } \\
\text { Groups }\end{array}$ & 0.57 & $\begin{array}{l}-0.609 \\
\left(-2.94^{*}\right)\end{array}$ & $\begin{array}{l}-0.943 \\
\left(-7.20^{*}\right)\end{array}$ & 12 & 0.51 & $\begin{array}{l}-1.015 \\
(-2.91 *)\end{array}$ & $\begin{array}{l}-1.001 \\
(-6.60 *)\end{array}$ & 9 & 0.56 & $\begin{array}{l}-0.995 \\
(-2.44 *)\end{array}$ & $\begin{array}{l}-1.012 \\
\left(-6.18^{*}\right)\end{array}$ & 9 \\
\hline $\begin{array}{l}\text { Government } \\
\text { Companies }\end{array}$ & 0.98 & $\begin{array}{l}0.082 \\
(0.81)\end{array}$ & $\begin{array}{l}-0.106 \\
(-0.27)\end{array}$ & 13 & 0.84 & $\begin{array}{l}0.191 \\
(1.80)\end{array}$ & $\begin{array}{l}0.219 \\
(0.11)\end{array}$ & 9 & 0.88 & $\begin{array}{l}0.094 \\
(0.33)\end{array}$ & $\begin{array}{l}0.181 \\
(0.04)\end{array}$ & 6 \\
\hline All Companies & & $\begin{array}{l}-0.105 \\
\left(-2.79^{*}\right)\end{array}$ & $\begin{array}{l}-0.366 \\
\left(-2.48^{*}\right)\end{array}$ & 543 & & $\begin{array}{l}-0.250 \\
(-5.27 *)\end{array}$ & $\begin{array}{l}-0.448 \\
(-3.23 *)\end{array}$ & 502 & & $\begin{array}{l}-0.373 \\
(-6.39 *)\end{array}$ & $\begin{array}{l}-0.501 \\
\left(-2.77^{*}\right)\end{array}$ & 485 \\
\hline
\end{tabular}


Table IX One-Way ANOVA Multiple Mean Comparison Test for Testing the Significant Difference Between the Long-Run Performance of Different Groups.

This table is based on data on 2,713 Initial Public Offerings (IPOs) issued in India during 1990-2004, on a yearly basis. The data are classified into four groups, based on the nature of the ownership of the firm making the IPO, namely, Private Indian Groups, Stand-Alone Companies, Government Companies and Private Foreign Groups. The initial return is calculated as the percentage of rate of change between the issue price and the first listing price on the stock exchange (Bombay Stock Exchange). A crore is 10 million and the current foreign exchange rate (October 2005) is about 45 Indian Rupees to one US \$. The Test of Differences is based on the Tukey Multiple Comparison Test. This test allows a simultaneous comparison of the means for multiple samples. For instance, in the case of the initial return variable, the Private Indian Group sample mean is compared with those of the other three groups. The Stand-Alone Companies sample is also compared in the same manner, but, leaving out the Private Indian Group sample, which was compared in the first set. * indicates values are significant at the $1 \%$ level. The $p$-values are in parentheses.

\begin{tabular}{|c|c|c|c|c|c|c|c|c|c|}
\hline $\begin{array}{l}\text { Variable } \\
\text { (i) }\end{array}$ & $\begin{array}{l}\text { Private } \\
\text { Indian } \\
\text { Groups }\end{array}$ & $\begin{array}{c}\text { Stand- } \\
\text { Alone } \\
\text { Companies } \\
\end{array}$ & $\begin{array}{c}\text { Government } \\
\text { Companies }\end{array}$ & $\begin{array}{c}\text { Private } \\
\text { Foreign } \\
\text { Groups } \\
\end{array}$ & $\begin{array}{l}\text { Variable } \\
\text { (i) }\end{array}$ & $\begin{array}{c}\text { Private } \\
\text { Indian } \\
\text { Groups }\end{array}$ & $\begin{array}{c}\text { Stand-Alone } \\
\text { Companies }\end{array}$ & $\begin{array}{l}\text { Government } \\
\text { Companies }\end{array}$ & $\begin{array}{l}\text { Private } \\
\text { Foreign } \\
\text { Groups } \\
\end{array}$ \\
\hline $\begin{array}{c}\text { AAR } \\
\text { (12 MONTHS) }\end{array}$ & & & & & $\begin{array}{c}\text { ARR } \\
\text { (24 MONTHS) }\end{array}$ & & & & \\
\hline $\begin{array}{l}\text { Private Indian } \\
\text { Groups }\end{array}$ & - & $\begin{array}{l}0.0091 \\
(0.972)\end{array}$ & $\begin{array}{l}0.0283 \\
(0.531)\end{array}$ & $\begin{array}{c}0.022 \\
(0.719)\end{array}$ & $\begin{array}{c}\text { Private Indian } \\
\text { Groups }\end{array}$ & - & $\begin{array}{l}0.0271 \\
(0.536)\end{array}$ & $\begin{array}{l}0.0361 \\
(0.279)\end{array}$ & $\begin{array}{l}0.0114 \\
(0.943)\end{array}$ \\
\hline $\begin{array}{c}\text { Stand-Alone } \\
\text { Companies }\end{array}$ & & - & $\begin{array}{l}-0.192 \\
(0.796)\end{array}$ & $\begin{array}{c}0.311 \\
(0.446)\end{array}$ & $\begin{array}{c}\text { Stand-Alone } \\
\text { Companies }\end{array}$ & & - & $\begin{array}{c}0.009 \\
(0.970)\end{array}$ & $\begin{array}{c}0.385 \\
(0.227)\end{array}$ \\
\hline $\begin{array}{c}\text { Government } \\
\text { Companies }\end{array}$ & & & - & $\begin{array}{l}0.0504 \\
(0.078)\end{array}$ & $\begin{array}{c}\text { Government } \\
\text { Companies }\end{array}$ & & & - & $\begin{array}{l}0.0475 \\
(0.088)\end{array}$ \\
\hline Private & & & & - & Private & & & & - \\
\hline Foreign & & & & & Foreign & & & & \\
\hline $\begin{array}{c}\text { Groups } \\
\text { ARR } \\
\text { (36 months) }\end{array}$ & & & & & Groups & & & & \\
\hline $\begin{array}{l}\text { Private Indian } \\
\text { Groups }\end{array}$ & - & $\begin{array}{c}0.005 \\
(0.993)\end{array}$ & $\begin{array}{c}0.025 \\
(0.557)\end{array}$ & $\begin{array}{l}0.0218 \\
(0.666)\end{array}$ & & & & & \\
\hline $\begin{array}{c}\text { Stand-Alone } \\
\text { Companies }\end{array}$ & & - & $\begin{array}{l}0.0199 \\
(0.725)\end{array}$ & $\begin{array}{l}0.0269 \\
(0.495)\end{array}$ & & & & & \\
\hline $\begin{array}{c}\text { Government } \\
\text { Companies }\end{array}$ & & & - & $\begin{array}{l}0.0468 \\
(0.070)\end{array}$ & & & & & \\
\hline $\begin{array}{l}\text { Private } \\
\text { Foreign } \\
\text { Groups }\end{array}$ & & & & - & & & & & \\
\hline
\end{tabular}




\section{Figure I Trends in the Number of Issues of IPOs by Various Categories of Firm Groups in India during 1990-2004}

This figure depicts the data on 2,713 Initial Public Offerings (IPOs) issued in India during 1990-2004, on a yearly basis, for the whole period and for sub-periods (regimes). The data are classified into four groups, based on the nature of the ownership of the firm making the IPO; namely, Private Indian Groups, Stand-Alone Companies, Government Companies and Private Foreign Groups. The initial return is calculated as the proportionate change between the issue price and the first listing price on the stock exchange (the Bombay Stock Exchange). We also include BSE 100 (a market bench mark index) annual return as a measure of Indian stock market trends during the same period. The data are also classified into three regimes based on the major structural changes that occurred in the Indian primary market. Regime 1 (Reg 1) (1990-95) is the IPO boom period, soon after the liberalization of the Indian economy, when the regulatory restrictions were mild. During Regime 2 (Reg 2) (1996-00), restrictions were introduced regarding pricing and other aspects of the issue. Regime 3 (Reg 3) (2001-04) is the period after the introduction of a more transparent book-building process for price discovery.

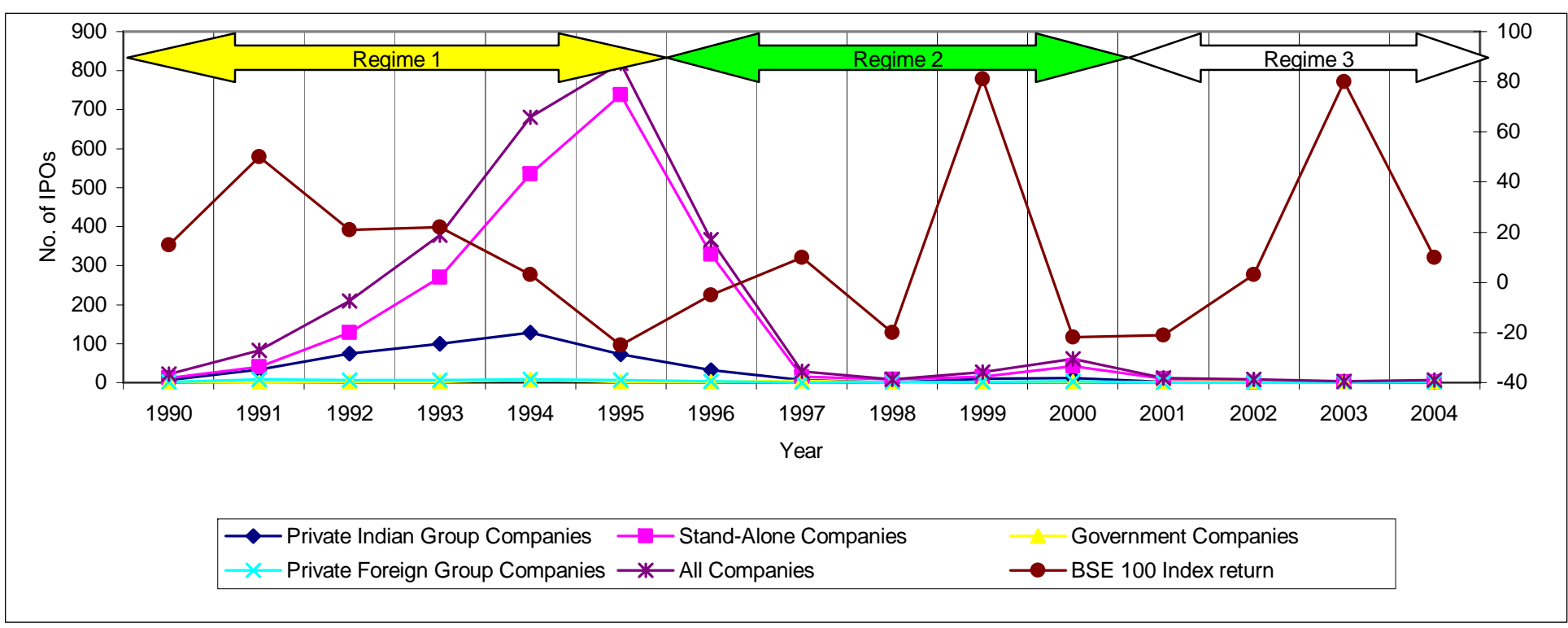




\section{Figure II Trends in the Initial Returns of IPO Issues by Various Categories of Firm Groups in India during 1990-2004}

This figure depicts the data on the initial returns of 2,713 Initial Public Offerings (IPOs) issued in India during 1990-2004, on a yearly basis, for the whole period and for subperiods (regimes). The data are classified into four groups, based on the nature of the ownership of the firm making the IPO; namely, Private Indian Groups, Stand-Alone Companies, Government Companies and Private Foreign Groups. The initial return is calculated as the proportionate change between the issue price and the first listing price on the stock exchange (the Bombay Stock Exchange). The data are also classified into three regimes based on the major structural changes that occurred in the Indian primary market. Regime 1 (Reg 1) (1990-95) is the IPO boom period, soon after the liberalization of the Indian economy, when the regulatory restrictions were mild. During Regime 2 (Reg 2) (1996-00), restrictions were introduced regarding pricing and other aspects of the issue. Regime 3 (Reg 3) (2001-04) is the period after the introduction of a more transparent bookbuilding process for price discovery. It should be noted that the peak of Private Foreign Group Companies in 1998 may be slightly misleading, since there is only one observation in the year 1998

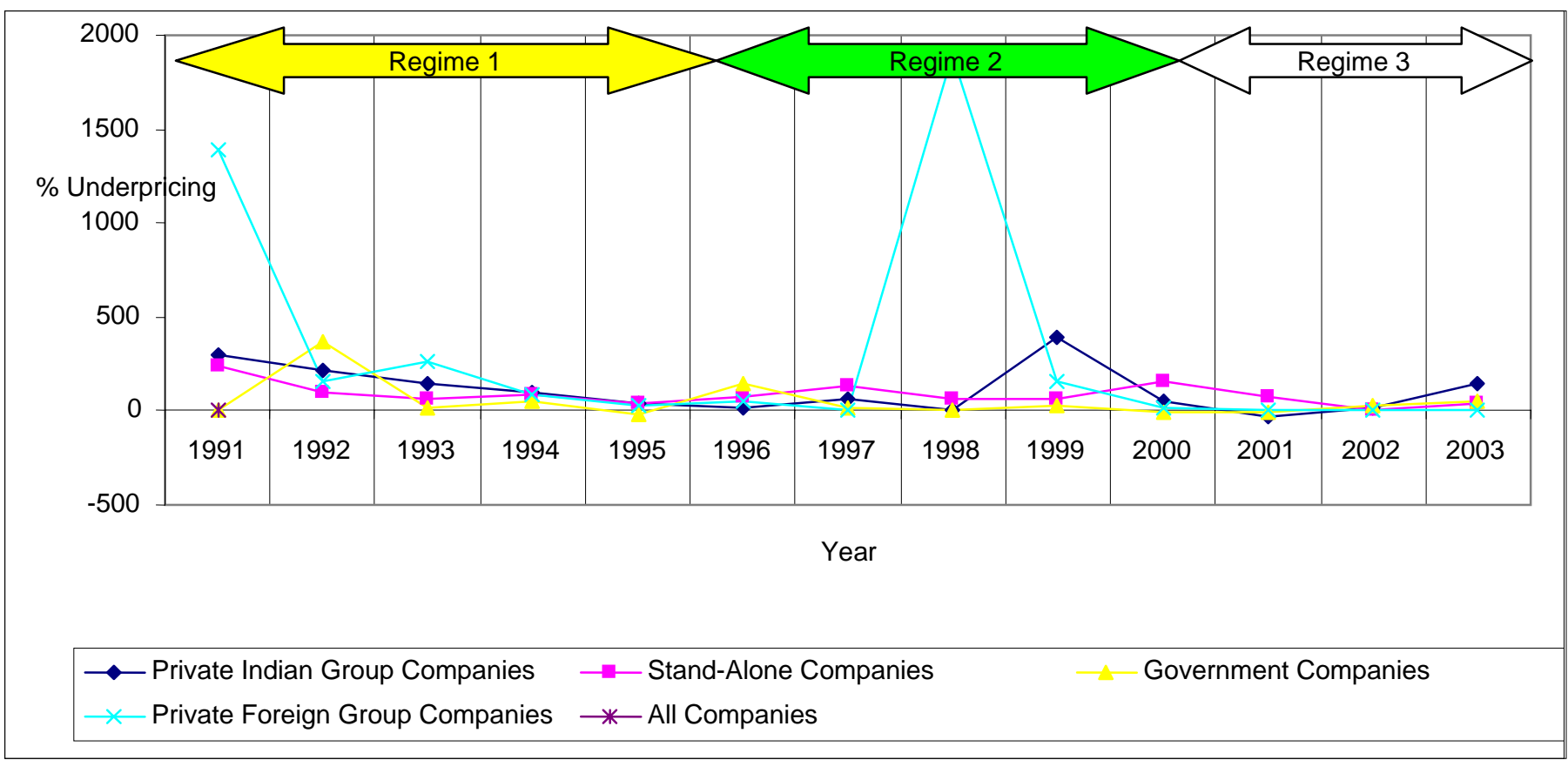

